\title{
A DIGNIDADE DA PESSOA HUMANA DO FIADOR E A PENHORA DO SEU BEM DE FAMÍLIA
}

\author{
DENISE ZIMMERMANN* \\ RAFAEL DE FREITAS VALLE DRESCH ${ }^{* *}$
}

\begin{abstract}
RESUMO: O presente estudo tem por escopo a questão da penhorabilidade do bem de família do fiador da locação e sua relação com o princípio da dignidade humana e da isonomia. A constitucionalidade do art. $3^{\circ}$, VII da Lei 8.009/90 frente ao art. $6^{\circ}$ da Constituição Federal foi declarada pelo Supremo Tribunal Federal em fevereiro de 2006. A análise apresenta, primeiramente, um viés doutrinário e jurisprudencial da aplicação do postulado da proporcionalidade em casos concretos, por ocasião do conflito entre a regra que determina a penhora, fundada no princípio da justiça comutativa e o princípio da dignidade da pessoa humana. A segunda análise, com ênfase na teoria e filosofia do direito, objetiva avaliar o conflito entre a regra que determina a penhora e o princípio da dignidade da pessoa humana nos termos de uma análise formalista (centrada no fundamento de justiça comutativa) e de uma análise funcionalista (centrada no fundamento de justiça distributiva). PALAVRAS-CHAVE: Bem de família; Fiador; Penhora; Dignidade humana; Isonomia; Locação.
\end{abstract}

ABSTRACT: The present study focus the issue of pawning the lease contract guarantor's homestead and the relation with human dignity and equality principles. The constitutionality of the article $3^{\circ}$, VII from Statute n. 8.009/90 in the relation to article $6^{\circ}$ from the Federal Constitution was declared by Federal Supreme Court in February, 2006. The analyses shows, at first, a doctrine and judicial view of the proportionality postulate application in concrete cases, in the conflict between the rule determines pawning, which was based on commutative justice and the human dignity principles. The second analyses emphasizing the theory and philosophy of law, aims to evaluate the conflict between the rule which determines the pawning and the human dignity principles in terms of a formalist analyses (focused on the grounds of commutative justice) and the functionalist analyses (focused on the grounds of distributive justice).

KEYWORDS: Homestead; Guarantor; Pledge; Human Dignity; Equality; Lease.

SUMÁRIO: 1. Introdução; 2. A moradia e o direito à moradia como direito fundamental social; 3. A regra e os princípios em jogo: justiça comutativa versus dignidade da pessoa humana; 4. Os Argumentos centrais da decisão do Supremo Tribunal Federal; 5. A solução pela proporcionalidade; 6 Conclusão; 7 Bibliografia.

Artigo recebido em 9.06.2009 e aprovado para publicação pelo Conselho Editorial em 23.06.2009.

* Advogada, Bacharel em Direito pelo Centro Universitário FEEVALE, Licenciada em Matemática (UNISINOS).

** Advogado, Doutorando em Direito (PUCRS), Mestre em Direito Privado (UFRGS), Especialista em Direito Contratual e Responsabilidade Civil (UFRGS), Professor da Pontifícia Universidade Católica do Rio Grande do Sul (PUCRS), do Centro Universitário FEEVALE e do Centro Universitário Metodista-IPA. 
SUMMARY: 1. Introduction; 2. The home and the right to homestead as a social fundamental right; 3 . The rule and the principles at stake: commutative justice versus the human person's dignity; 4. The central arguments of the Supreme Federal Court's decision; 5. The solution through proportionality; 6. Conclusion; 7. Bibliography.

\section{INTRODUÇÃO}

O tema do presente estudo se refere à relação entre dignidade da pessoa humana do fiador no contrato de locação de imóvel e a penhora do seu bem de família. Para que o seu objetivo seja alcançado, é necessário que uma questão seja respondida: É possível a penhora do bem de família do fiador, no contrato de locação em vista da Lei do Bem de Família (Lei ${ }^{\circ}$ 8.009/90) e do direito à moradia inserido na Constituição Federal pela Emenda Constitucional no 26, de 14 de fevereiro de 2000?

$\mathrm{O}$ intérprete deve obedecer à regra que manda penhorar o bem de família do fiador ou pode aplicar o postulado da proporcionalidade, ante o conflito entre a regra e o princípio, para garantir a dignidade da pessoa do fiador, no caso concreto?

As relações contratuais entre locador e locatário e a consequente chamada do fiador à relação processual, por ocasião de inadimplemento das obrigações contratuais, geram inúmeras situações cuja solução demandada junto aos Tribunais, sendo difícil alcançar um tratamento que contemple a igualdade que a Constituição Federal determina e garante, no sentido de fazer justiça a todos, sejam locadores, sejam locatários e fiadores.

Ao contratar a locação de um bem imóvel, o locador se obriga a ceder a posse do bem objeto do contrato, assim como o locatário se obriga a pagar as prestações relativas ao aluguel e o fiador se obriga no contrato acessório de fiança. Havendo inadimplemento e interposta ação executiva do crédito oriundo do contrato de locação, ao afiançado/locatário é garantida a impenhorabilidade do seu bem de família e, consequentemente, o seu direito à moradia; mas ao fiador, de forma contrária, a garantia da impenhorabilidade não lhe é dada, resultando com isso a perda do seu bem de família e, por consequência, comprometendo também o seu direito à moradia.

O Supremo Tribunal Federal, em fevereiro de 2006, decidiu pela constitucionalidade da penhora do bem de família do fiador da locação, mas apesar da discussão relativa à aplicação da regra e suas consequências para a pessoa do fiador, a solução apresentada não acalma os ânimos exaltados em torno do tema. O tratamento dado pelo Supremo Tribunal Federal à matéria relativa à análise do princípio da isonomia aplicado às partes na ação executiva, ou seja, ao afiançado e fiador, não contentou ministros e alguns doutrinadores, que se levantam para clamar pela aplicação desse princípio constitucional.

É meta deste estudo, na forma de pesquisa jurisprudencial e doutrinária, traçar diretrizes com o intuito de proceder à aplicação do postulado da proporcionalidade em casos concretos retirados da jurisprudência, por ocasião do conflito entre a regra que determina a penhora fundada no princípio da justiça comutativa e a dignidade da pessoa humana.

Ademais, a presente análise, com ênfase na teoria e filosofia do direito, objetiva avaliar o conflito entre a regra que determina a penhora e o princípio da dignidade da 
pessoa humana nos termos de uma análise formalista (centrada no fundamento de justiça comutativa) e de uma análise funcionalista (centrada no fundamento de justiça distributiva) ${ }^{1}$. O pano de fundo da discussão é dado pela decisão do Supremo Tribunal Federal que, se posicionando em favor da constitucionalidade da regra que permite a penhora, adotou argumentos distintos centrados em um voluntarismo formalista e em um utilitarismo funcionalista. Assim, o estudo se dirige aqueles que entendem que uma decisão, mesmo sendo de última instância, dada pelo tribunal de maior autoridade, pode estar equivocada ${ }^{2}$.

Com efeito, em 8 de fevereiro de 2006, no julgamento do Recurso Extraordinário $n^{\circ}$ 407.688-8, cuja relatoria foi do Ministro Cezar Peluso, a maioria dos ministros participantes do julgamento entendeu constitucional, ante o direito fundamental à moradia previsto no art. $6^{\circ}$ da Constituição Federal, a regra que permite a penhora do imóvel residencial do fiador nos termos do art. $3^{\circ}$, inciso VII, da Lei Federal $n^{\circ} 8.009 / 90$, na versão que lhe deu a Lei Federal $n^{\circ} 8.245 / 91$.

Dos votos condutores da maioria, deve-se destacar o voto do relator, Ministro Cezar Peluso que se baseou no argumento funcionalista (mais especificamente utilitarista $^{3}$ ), centrado numa análise de justiça distributiva, de que a penhora do bem de família do fiador garante o direito à moradia através da maior oferta de imóveis no mercado. Ou seja, a regra é constitucional porque maximiza o bem-estar geral ao garantir maior oferta de imóveis para locação - diante de uma fiança reforçada pela penhorabilidade - e consequente diminuição do risco dos locadores. Diminuindo o risco, maior será a oferta e menor será o preço pago pelo público em geral para acessar a moradia através de contratos de locação.

O segundo argumento a embasar a decisão pela constitucionalidade foi apresentado pelos ministros Joaquim Barbosa, Gilmar Mendes e Sepúlveda Pertence. Tais julgadores defenderam a posição pela constitucionalidade da regra da penhora com base no fato de que o fiador se obriga voluntariamente, portanto, no pleno exercício da sua autonomia de vontade, podendo, de tal forma, abrir mão de sua proteção ao bem de família. A voluntariedade, centrada na suposta liberdade do indivíduo negociar seu direito fundamental à moradia, é defendida em termos formalistas a partir da ideia de justiça corretiva como será desenvolvido abaixo.

Como será demonstrado neste estudo, configurando justamente uma hipótese a ser confirmada, os argumentos pela constitucionalidade da penhora do bem de família do fiador não são sustentáveis nem numa visão utilitarista, com base na justiça distributiva, nem numa visão formalistas, com base na justiça corretiva e no voluntarismo.

${ }^{1}$ Sobre o funcionalismo e o formalismo na compreensão do direito privado e de seus institutos ver: WEINRIB, Ernest J. The idea of private law. Havard Cambridge: University Press, 1995, e, na doutrina nacional, MICHELON JÚNIOR, Cláudio. Um ensaio sobre a autoridade da razão. Revista da Faculdade de Direito da Universidade Federal do Rio Grande do Sul, Porto Alegre: v. 21, mar. 2002.

${ }^{2}$ Sobre o debate jurídico-filosófico referente a julgamentos equivocados em última instância vide MACCORMICK,

Neil. Retórica e Estado de Direito. Trad. Conrado Hubner Mendes, Rio de Janeiro: Elsevier, 2008, pp.329 ss.

${ }^{3}$ Sobre as características do utilitarismo ver o ensaio de KYMLICKA, Will. Filosofia Política Contemporânea.

Trad. Luís Carlos Borges, São Paulo: Martins Fontes, 2006, pp. 11-62. 
2. A MORADIA E O DIREITO À MORADIA COMO DIREITO FUNDAMENTAL SOCIAL

\subsection{O direito à moradia $\mathrm{e}$ o direito de propriedade}

O direito à moradia é um bem irrenunciável da pessoa natural que não pode ser dissociado de sua vontade, e indisponível, pois permite o seu estabelecimento em lugar determinado ${ }^{4}$, não somente de forma física, mas também o estabelecimento dos interesses da vida natural do indivíduo, sendo, pois, objeto de direito e tutelado juridicamente. Sérgio I. N. de Souza escreve que o bem da moradia se diferencia da residência, pois esta é o local onde o indivíduo se encontraria e a habitação é o "exercício efetivo da moradia” sobre um determinado imóvel. Como direito de natureza essencial, o direito à moradia qualifica de forma legal a moradia. ${ }^{5}$

O direito à moradia é um direito humano entendido, dessa forma, pelo direito internacional e órgão internacionais ${ }^{6}$. O fundamento do direito à moradia encontra-se no direito natural ${ }^{7}$, tendo como origem o seu reconhecimento através do art. 25 da Declaração Universal dos Direitos Humanos da ONU (1948) e do art. 11 do Pacto Internacional dos Direitos Econômicos, Sociais e Culturais. ${ }^{8}$

No art. $6^{\circ}$ da Constituição Federal de 1988 encontram-se contemplados os direitos

\footnotetext{
4 “O direito à moradia significa ocupar um lugar como residência; ocupar uma casa, apartamento etc., para nele habitar. No 'morar' encontramos a idéia básica da habitualidade no permanecer ocupando uma edificação, o que sobressai com sua correlação como residir e o habitar, com a mesma conotação de permanecer ocupando um lugar permanentemente”. (SILVA, José Afonso da. Curso de Direito Constitucional Positivo. 22. ed. rev. e atual. São Paulo: Malheiros, 2003, p. 313).

5 SOUZA, Sérgio Iglesias Nunes de. Direito à moradia e de habitação: análise comparativa e suas implicações teóricas com os direitos de personalidade. São Paulo: Ed. Revista dos Tribunais, 2004, p. 45.

${ }^{6}$ Sarlet entende ser o direito à moradia um "direito humano (reconhecido e protegido na esfera internacional) e fundamental (constitucionalmente assegurado). (SARLET, Ingo Wolfgang. O direito Fundamental à moradia na Constituição: algumas anotações a respeito de seu contexto, conteúdo e possível eficácia. In: Revista de Direito do Consumidor. n 46, abril-junho, 2003. Ed. Revista dos Tribunais, p.196). "O direito à moradia é tutelado e protegido pelas seguintes normas: Declaração Universal dos Direitos Humanos; Convenção Internacional dos Direitos Econômicos, Sociais e Culturais; Convenção Americana de Direitos Humanos - Pacto de San José da Costa Rica, e por outros tratados e pactos internacionais, como a Declaração sobre o Direito ao Desenvolvimento de 1986; a Declaração Americana dos Direitos e Deveres do homem; a Convenção Relativa ao estatuto dos Refugiados; o Pacto Internacional dos Direitos Civis e Políticos; a Convenção Internacional sobre a Eliminação de todas as Formas de Discriminação Racial; a Convenção sobre os Direitos da Criança e na Declaração sobre Assentamentos Humanos de Vancouver”. (SOUZA, Sérgio Iglesias Nunes de. Direito à moradia e de habitação, p. 342).

José Reinaldo de Lima Lopes explica que “[...] a atual perspectiva do direito à moradia funda-se originariamente na idéia de direito à vida. [...] O direito à vida, para nós, é também hoje em dia direito à vida digna e à integração social”. (LOPES, José Reinaldo de Lima. Direitos Sociais: teoria e prática. São Paulo: Método, 2006, p. 84 et seq.).

${ }^{8}$ Ingo W. Sarlet, em artigo sobre o tema, disserta que "verifica-se ter sido na Declaração Universal dos Direitos Humanos da ONU (1948), onde pela primeira vez, restou consignado o reconhecimento, pela ordem internacional, dos assim denominados direitos econômicos, sociais e culturais, dentre os quais o direito à moradia. Com efeito, de acordo com o artigo XXV (1) da Declaração: 'todos têm direito ao repouso e ao lazer, bem como a um padrão de vida capaz de assegurar a si e a sua família saúde e bem-estar, inclusive alimentação, vestuário, habitação, cuidados médicos, e serviços sociais indispensáveis, o direito à segurança em caso de desemprego, doença, invalidez, viuvez, velhice, ou outros casos de perda dos meios de subsistência em circunstâncias fora de seu controle”. (SARLET, Ingo Wolfgang. O Direito Fundamental à Moradia na Constituição, p. 203).
} 
sociais, dentre eles o direito à moradia. José Afonso da Silva conceitua os direitos sociais como aqueles cuja prestação positiva é proporcionada pelo Estado de forma direta ou indireta, expressas nas normas constitucionais de forma a possibilitar aos mais fracos melhores condições de vida, com o intuito de dirimir o desnível social. ${ }^{9}$

Até a Constituição Federal de 1988, o direito à moradia não tinha sido expressamente previsto, sendo protegido de forma genérica apenas pela aplicabilidade do $\S 2^{\circ}$ do art. $5^{\circ}$ da Constituição Federal ${ }^{10}$. Com o advento da Emenda Constitucional $\mathrm{n}^{\mathrm{o}} 26$, de 14 de fevereiro de 2000 , o direito à moradia ${ }^{11}$ foi inserido no art. $6^{\circ}$ da Constituição Federal de 1988 como direito social ${ }^{12}$ e constitui uma das formas também de tutela pessoal, obedecendo ao comando do $\S 1^{\circ}$ do art. $5^{\circ}$ da Constituição Federal de 1988, outorgando aplicação imediata às normas definidoras dos direitos e garantias fundamentais. ${ }^{13}$

${ }^{9}$ SILVA, José Afonso da. Curso de Direito Constitucional Positivo, p. 286.

${ }^{10} \mathrm{O}$ Art. $5^{\circ}$, § $2^{\circ}$ da Constituição Federal de 1988 dispõe que: Os direitos e garantias expressos nesta Constituição não excluem outros decorrentes do regime e dos princípios por ela adotados, ou dos tratados internacionais em que a República Federativa do Brasil seja parte. A Emenda Constitucional 45/2004, dentre outras alterações, incluiu o $\S 3^{\circ}$ ao art. $5^{\circ}$ da Constituição Federal, dispondo: Os tratados e convenções internacionais sobre direitos humanos que forem aprovados, em cada Casa do Congresso Nacional, em dois turnos, por três quintos dos votos dos respectivos membros, serão equivalentes às Emendas Constitucionais. Érica Pessanha escreve sobre o tema dizendo que “[...] é perceptível no Brasil que o problema da eficácia dos direitos fundamentais e, principalmente, dos direitos sociais prestacionais, deve merecer relevante atenção no âmbito dos três Poderes, para que comece a produzir no mundo dos fatos o que já se garantiu normativamente na Constituição”. (PESSANHA, Érica. A eficácia dos direitos sociais prestacionais. Disponível em: <http://www.fdc.br/Arquivos/Mestrado/Revistas/Revista08/Discente/Erica.pdf... Acesso em: 22 mar. 2007).

11 “Além da previsão do caput do art. 6º o direito à moradia será mencionado expressamente mais duas vezes na Constituição Federal no art. 21, XX, que diz que compete à União instituir diretrizes para o desenvolvimento urbano, inclusive habitação, saneamento básico, transportes urbanos, e no art. 23, IX, ao dispor que é competência comum da União, dos Estados, do Distrito Federal e dos Municípios promover programas de construção de moradias e a melhoria das condições habitacionais e de saneamento básico. [...] a norma constitucional apenas fixa a moradia como direito social e estabelece competência comum aos entes da Federação para realizar programas de habitação”. (VIOLA, Luis Armando. O Direito Social “moradia" com o advento da Lei $n^{\circ}$ 10.257, de 10.07.2001 (Estatuto da Cidade). In: Interesse Público. Ano 8, $n^{\circ}$ 37, maio/junho de 2006. Porto Alegre: Notadez, p. 340).

12 "Os direitos sociais incorporam o quadro dos direitos fundamentais a partir da I Guerra Mundial e se expressam através de ações positivas do Estado para garantir sua efetivação. [...] o direito à moradia é essencialmente um direito social e sua sindicabilidade plena condiciona-se a ações positivas do Estado, ou seja, um agir estatal no sentido de proporcionar moradia à coletividade titular de direitos. (VIOLA, Luis Armando. O direito social “moradia”...., p. 337-8).

${ }^{13}$ SOUZA, Sérgio Iglesias Nunes de. Direito à Moradia e de Habitação, p. 344. Maria Cristina Zucchi comenta a respeito da inserção do direito à moradia no art. $6^{\circ}$ da Constituição Federal que "para os que entendem tratar-se de garantia tão elevada e reforçada a ponto de inseri-la no mesmo âmbito dos direitos e garantias individuais, os direitos sociais fruem de intangibilidade que os coloca além do alcance do poder ordinário”. (ZUCCHI, Maria Cristina. O bem de família e a garantia da fiança locatícia. Francisco Antonio Casconi e José Roberto Neves Amorin (coords.). In: Locações - Aspectos relevantes - Aplicação do novo Código Civil. São Paulo: Método, 2004, p. 174). Em relação à aplicação imediata das normas definidoras dos direitos e garantias fundamentais, Manoel Gonçalves Ferreira Filho diz que a intenção dos constituintes foi louvável, mas que o caminho que os legisladores escolheram não é suficiente para alcançar o objetivo pretendido. "É lição da doutrina clássica, totalmente aceita, a de que nem toda norma constitucional é suscetível de aplicação imediata. Donde se pode perfeitamente inferir que uma norma constitucional, mesmo definidora de direitos ou garantias fundamentais, somente pode ser aplicada se for completa. [...] 
Deve partir do Estado a iniciativa e o dever de concretizar o direito à moradia através da construção e distribuição de moradias por ele construídas e mantidas, ou então, mediante subsídios à locação, com a aplicação de critérios definidores quanto à necessidade de cada indivíduo e acesso também para aqueles que vivem em abrigos, não esquecendo de que a moradia seja compatível com a exigência mínima para uma vida humana digna e decente. ${ }^{14}$

Como principal fundamento para explicar que o direito à moradia encontra-se vinculado diretamente com a dignidade da pessoa humana, Ingo Sarlet escreve o que segue:

[...] provavelmente é ao direito à moradia - bem mais do que ao direito de propriedade - que melhor se ajusta a conhecida frase de Hegel, ao sustentar - numa tradução livre - que a propriedade constitui (também) o espaço de liberdade da pessoa [...]. Com efeito, sem um lugar adequado para proteger-se a si próprio e a sua família contra as intempéries, sem um local para gozar de sua intimidade e privacidade, enfim, de um espaço essencial para viver com um mínimo de saúde e bem-estar, certamente a pessoa não terá assegurada a sua dignidade, aliás, por vezes não terá assegurado o direito à própria existência física, e, portanto, o seu direito à vida. [...] o direito à moradia tem sido, também entre nós - e de modo incensurável - incluído no elenco dos assim designados direitos de subsistência, como expressão mínima do próprio direito à vida. ${ }^{15}$

O direito à moradia deve ser tratado como um instrumento compatível com a dignidade da pessoa humana, pois envolve outros bens conexos da personalidade tais como a honra, o nome, a intimidade, finalmente a integridade física, psíquica e moral do indivíduo, reclamando preservação e proteção por parte do Estado e dos indivíduos. $^{16}$

Em conclusão, somente podem aplicação imediata normas completas, suficientemente precisas na sua hipótese e no seu dispositivo, para que possam ter a sua plenitude da eficácia”. (FERREIRA FILHO, Manoel Gonçalves. Curso de Direito Constitucional. 26. ed. atual. São Paulo: Saraiva, 1999, p. 307-8).

${ }^{14}$ VIOLA, Luis Armando. O Direito Social “moradia”..., p. 342. Pode-se ainda acrescentar que "Ao adotar, em 13 de maio de 1996, o Programa Nacional de Direitos Humanos, o Brasil se tornou um dos primeiros países do mundo a cumprir recomendação específica da Conferência Mundial de Direitos Humanos (Viena, 1993) atribuindo ineditamente aos direitos humanos o status de política pública governamental”. Nesse mesmo texto, que engloba 518 propostas de ações governamentais, compondo o então PNDH II, transcrevemos uma pequena parte da introdução redigida pelo então presidente da República em exercício, Fernando Henrique Cardoso: “A implementação das diretrizes do Programa Nacional de Direitos Humanos, ao longo dos últimos seis anos, abriu novas perspectivas de transformação no modo como a sociedade brasileira enfrenta o seu cotidiano, em busca constante por justiça e por melhores condições de vida. Fortaleceram-se as garantias de que dispõem os brasileiros contra o arbítrio do Estado, a prática da violência, o desrespeito dos direitos fundamentais. [...] Sabemos que a promoção e a proteção dos direitos humanos é tarefa que cabe a todos nós: cidadãos e autoridades. [...] O Novo Programa Nacional dos Direitos Humanos oferece um mapa das rotas que devemos trilhar, nos próximos anos - mediante ações do governo e da sociedade - para avançar, com impulso ainda maior, no projeto de construção de um Brasil mais justo". Disponível em: <http://www.mj.gov.br/sedh/pndh/pndhII/texto_integral_pndhii.pdf > Acesso em: 3 dez. 2006.

${ }^{15}$ SARLET, Ingo Wolfgang. O Direito Fundamental à Moradia na Constituição, p. 209.

${ }^{16}$ SOUZA, Sérgio Iglesias Nunes de. Direito à Moradia e de Habitação, p. 351. 
No direito à moradia o elemento central é o direito humano, extrapatrimonial, inerente à pessoa e independe de objeto físico para a sua existência. Mas sem a posse, o indivíduo não pode exercer o seu direito à moradia, pois ela é um elemento essencial ao exercício de fato $^{17}$ das faculdades do domínio sobre a coisa, no sentido de usar e fruir dos direitos da propriedade imóvel que passa a ser objeto de moradia.

Cabe ainda distinguir o direito à moradia do direito de propriedade, sendo importante acrescentar a referência de José Afonso da Silva, no sentido de que “o direito à moradia não é necessariamente direito à casa própria”, mas a garantia de um teto para abrigar a família ${ }^{18}$ “de modo permanente”, com dimensões adequadas, "higiene e conforto e que preserve a intimidade pessoal e a privacidade familiar"19, sendo amparado pelo princípio da dignidade da pessoa humana. A moradia individual e familiar, como bem essencial à vida digna, portanto, "não se confunde com o direito de propriedade sobre um bem imóvel”. ${ }^{20}$ Invocar a proteção do direito à moradia é distinto de invocar a proteção do direito de propriedade ${ }^{21}$, pois não há como confundir estas duas garantias. O direito de propriedade, trazendo consigo as faculdades da propriedade e do domínio ${ }^{22}$, estende a todos a possibilidade de

${ }^{17}$ O Código Civil de 2002, em seu artigo 1.196 dispõe que: considera-se possuidor todo aquele que tem de fato o exercício, pleno ou não, de algum dos poderes inerentes à propriedade. Nesse mesmo sentido, Caio Mário acrescenta que a posse, nascendo de uma relação de fato, converte-se de pronto numa relação jurídica. (PEREIRA, Caio Mário da Silva. Instituições de Direito Civil. Vol. IV. Direitos Reais. Rio de Janeiro: Forense, 2003, p. 27).

${ }^{18}$ Importante acrescentar a contribuição de Eugênio Facchini Neto a respeito da nova imagem da família comparada a “[...] a imagem 'ninho', evoca a sensação de aconchego, de calor, de proteção, de um lugar que serve de refúgio para que os seres ali criados cresçam, desenvolvam-se, fortaleçam-se, sendo cuidados e protegidos até que estejam em condições de alçar vôo par suas vidas autônomas, formando suas próprias famílias”. (FACCHINI NETO, Eugênio. A função social do direito privado... In: Revista da Ajuris. Ano XXXIV. No 105 . Março de 2007, p. 176).

${ }^{19}$ SILVA, José Afonso da. Curso de Direito Constitucional Positivo, p. 313.

${ }^{20}$ MENKE, Cassiano. A proibição aos efeitos de confisco no direito tributário. Porto Alegre: UFRGS, 2006. Dissertação (Mestrado em Direito), Faculdade de Direito, Universidade do Rio Grande do Sul, 2006, p. 105.

${ }^{21}$ Eduardo Cambi escreve que, na conceituação da propriedade dentro do Novo Código Civil, "Subordinar o exercício do direito de propriedade às suas finalidades econômicas e sociais significa limitar este direito, que deixa de ser visto como um direito absoluto, para ser compreendido a partir de sua função, à semelhança do contrato, cuja liberdade fica limitada em razão e nos limites da função social do contrato (art. 421/NCC). [...] Pelo NCC, a propriedade, sem deixar de ser um direito subjetivo, um jus, passa a ser considerada, também um munus, exprimindo, simultaneamente, um direito e um dever. Assim, deixa de ser um direito pleno, retirando-se da propriedade privada sua incondicional prevalência, e, destarte, não se legitimando todo e qualquer ato de omissão do proprietário, na medida em que seu conteúdo depende de interesses extraproprietários, inseridos na relação jurídica de propriedade, pelo estatuto jurídico que dá configuração à sua função social”. (CAMBI, Eduardo. Propriedade no Novo Código Civil: Aspectos Inovadores. In: Revista Síntese de Direito Civil e Processual Civil. v.1, nº 1, set/out. 1999, p. 124/5).

22 José Reinaldo de Lima Lopes a respeito do direito de propriedade e do direito à moradia escreve o seguinte: “A compreensão tradicional do direito de propriedade precisa ser alterada e ampliada. E isto requer atenção à realidade que nos cerca. [...] De um certo ponto de vista o direito à moradia não passa de um direito à propriedade de uma casa, um objeto ou bem imóvel. [...] Dar direito à casa (enquanto mercadoria) é considerado tarefa do Estado. [...] Assim, para dar casa, nestes termos, nada mais evidente e óbvio do que estimular uma indústria de construção civil. E não só estimular esta indústria, como associála a um sistema financeiro. Vejam esta lógica: moradia reduz-se a propriedade de uma casa (bem imóvel), coisa é mercadoria, o sistema de mercado é o que mais consegue produzir mercadorias, logo, estabeleçamos um sistema de mercado”... (LOPES, José Reinaldo de Lima. Direitos Sociais, p. 74). 
adquirir, manter e dispor da propriedade dentro dos limites constitucionais, expressando dessa forma a manifestação do princípio da liberdade. ${ }^{23}$

\subsection{A proteção do direito à moradia e os reflexos no contrato de locação de imóvel}

A proteção ao direito à moradia tem se manifestado de várias formas, como se pode enunciar: nos casos de acesso a uma habitação, através da posse direta na locação de um imóvel residencial; da criação de linhas de financiamento específicas, facilitando a aquisição ou construção de residências especialmente para pessoas de baixo poder aquisitivo ou através de sistemas de mutirões de construções ${ }^{24}$. Também tem se mostrado através da possibilidade de aquisição da propriedade pela usucapião de

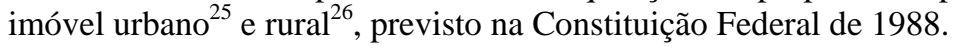

A proteção do direito à moradia aparece nos casos de contrato de locações pela proteção da Lei $n^{0} 8.245 / 91$ que, busca privilegiar o direito à moradia nos contratos para fins residenciais ${ }^{27}$; nos casos de propriedade da residência familiar, a proteção da Lei $n^{\circ} 8009 / 90$, Lei do Bem de Família, criada para proteger o único imóvel que serve de residência para família ou entidade familiar, salvo nos casos previstos pela mesma lei $^{28}$; nos contratos de leasing residencial ou arrendamento residencial ${ }^{29}$

\footnotetext{
${ }^{23}$ Para José Afonso da Silva, o conceito de liberdade deve ser expresso como "um poder de atuação do homem em busca de sua realização pessoal, de sua felicidade. [...] O princípio é o de que todos têm a liberdade de fazer e de não fazer o que bem entender, salvo quando a lei determine em contrário. [...] $a$ liberdade só pode ser condicionada por um sistema de legalidade legítima”... (SILVA, José Afonso da. Curso de Direito Constitucional Positivo, p. 232/9).

${ }^{24}$ Souza explica que o direito de habitação deve ser analisado "sob o enfoque do direito à moradia", e que "os contratos celebrados que envolvam o direito de habitação sobre determinado imóvel, [...] deverão sofrer uma interpretação não só com relação aos princípios gerais e específicos do direito contratual envolvido [...], mas também em relação aos princípios que protegem a personalidade humana, refletindo, por conseqüência, o reconhecimento do direito à moradia em razão e nos limites da função social do contrato [...]”. (SOUZA, Sérgio Iglesias Nunes de. Direito à moradia e de habitação, p. 350/1).

25 “O novo 'Estatuto da Cidade' (Lei $\mathrm{n}^{\circ}$ 10.257/2001), editado mais de década após a promulgação da Constituição, já que se cuida inequivocamente de instrumento essencial para uma maior eficácia e efetividade do direito à moradia na ordem jurídica brasileira”. (SARLET, Ingo Wolfgang. O direito Fundamental à moradia na Constituição, p. 231).

${ }^{26}$ A propriedade rural ou agrária está submetida ao regime legal definido na Constituição Federal de 1988, arts. 183 e 191, no Estatuto da Terra (Lei n 4.504, de 1964) e em lei complementares. "Nesse regime, a idéia da propriedade/função social foi aceita através da predeterminação de seu exercício. A propriedade do imóvel rural se exerce como uma função social quando favorece o bem-estar dos seus proprietários e trabalhadores, mantendo níveis satisfatórios de produtividade, assegura a conservação dos recursos naturais e observa a regulamentação legal do trabalho”. (GOMES, Orlando. Direitos Reais. 19. ed. atualizada / por Luiz Edson Fachin. Rio de Janeiro: Forense, 2005, p. 122).

${ }^{27}$ José Rogério Cruz e Tucci, em artigo sobre matéria envolvendo o direito à moradia escreve que, "Não é preciso repetir que a facilitação à celebração do contrato de locação, inclusive com a intervenção de fiador que não tenha avantajado patrimônio, constitui importante incentivo ao direito à moradia!”. (TUCCI, José Rogério Cruz e. A penhora sobre o bem do fiador de locação. In: A penhora e o bem de família do fiador da locação. Coordenação José Rogério Cruz e Tucci. Ed. Revista dos Tribunais, 2003, p. 21).

28 "Observe-se que, efetivamente, no exercício do direito de habitação, existe até a disponibilidade ou a faculdade de o fiador dar em garantia o seu próprio imóvel, ainda que ali resida [...]”. (SOUSA, Sérgio Iglesias Nunes de. Direito à moradia e de habitação, p. 272).

29 “Leasing residencial, disposto pela Lei 10.188, de 12.02.2001 e destinado à população de baixa renda $\left(\right.$ art. $\left.1^{\circ}\right)$ [...]”. (SOUZA, Sérgio Iglesias Nunes de. Direito à moradia e de habitação, p. 283).
} 
ou ainda através de contratos de concessão de uso de direito real de habitação pelo Poder Público. ${ }^{30}$

Outro enfoque importante a ser dado ao direito à moradia como direito fundamental é que os direitos fundamentais podem exercer a função defensiva ${ }^{31}$ ou prestacional, dependendo da situação envolvida. No caso em tela, o direito à moradia assume a dimensão negativa, com a conotação de direito de defesa (negativo) ${ }^{32}$. Como escreve Sarlet, os direitos de defesa constituem em princípio, “direito subjetivo individual, enquadrando-se [...] naquelas situações em que a norma constitucional outorga ao particular uma situação subjetiva ativa (um poder jurídico), cujo desfrute imediato depende de qualquer prestação alheia, bastando, para tanto [...] uma atitude abstencionista por parte do destinatário da norma”."33

\section{A REGRA E OS PRINCÍPIOS EM JOGO: JUSTIÇA COMUTATIVA VERSUS DIGNIDADE DA PESSOA HUMANA}

\subsection{A regra penhorar e a dignidade da pessoa humana do fiador}

A Lei 8.009/90, de 29.03.1990, Lei do Bem de Família ou Lei Sarney como ficou conhecida, dispõe sobre a impenhorabilidade ${ }^{34}$ do imóvel residencial próprio da família ou entidade familiar. A impenhorabilidade legal do bem de família não é absoluta, pois a própria norma legal estabelece as exceções expressas no art. $3^{\circ}$ da mesma lei ${ }^{35}$. O inciso VII do art. $3^{\circ}$ foi acrescentado pelo art. 82 da Lei $n^{\circ} 8.245$, de 18.10.1992, que regula a locação de imóveis urbanos ${ }^{36}$. Por decorrência dessa inclusão no rol das exceções do art. $3^{\circ}$ da Lei $n^{\circ} 8.009 / 90$, o imóvel residencial do fiador,

\footnotetext{
${ }^{30}$ SOUZA, Sérgio Iglesias Nunes de. Direito à moradia e de habitação, p. 349.

${ }^{31}$ ALEXY, Robert. Teoria de los derechos fundamentales. Madrid: CEC, 1991, p. 419/41.

${ }^{32}$ SARLET, Ingo Wolfgang. O direito Fundamental à moradia na Constituição, p. 217.

${ }^{33}$ Sarlet escreve ainda que, "nas relações entre particulares, onde o direito à moradia, notadamente (mas não exclusivamente) na sua dimensão defensiva, também alcança eficácia e vinculatividade, igualmente são comuns as situações de conflito entre o direito à moradia e outros bens fundamentais salvaguardados pela Constituição, destacando-se o direito de propriedade (como pode ocorrer numa ação movida pelo locador proprietário contra o inquilino). Da mesma forma, verifica-se a ocorrência de conflitos (ou colisões, se preferimos) entre o direito à moradia de pessoas situadas em pólos opostos da demanda, por vezes ambos igualmente carentes de recursos, do que dão conta os casos - cada vez menos raros - de ações de reintegração de posse intentadas por pessoas que tiveram seu casebre edificado em 'área verde' ocupado (até mesmo quando se encontravam no trabalho) por terceiros, ainda que igualmente ou até mesmo mais humildes e carentes”. (SARLET, Ingo Wolfgang. O direito Fundamental à moradia na Constituição, p. 228).

${ }^{34}$ Lei n. 8.009/90, art. $1^{\circ}$, o imóvel que serve de residência é impenhorável e não responderá por qualquer tipo de dívida, civil, comercial, fiscal, previdenciária ou de outra natureza, contraída pelos cônjuges ou pelos pais ou filhos que sejam proprietários e nele residam, salvo nas hipóteses previstas nesta lei. Segundo Araken de Assis, quando a lei impõe restrições à execução de determinados bens, considerando-os impenhoráveis ou inalienáveis, como dispõe o art. 684 do Código de Processo Civil, "por tal razão, as restrições recebem a designação genérica de impenhorabilidade”... (ASSIS, Araken de. Manual de execução. 9. ed. rev. e atual. e ampl. São Paulo: Ed. Revista dos Tribunais, 2004, p. 196).

${ }^{35}$ Lei 8.009/90, artigo $3^{\circ}$, caput e inciso VII: A impenhorabilidade é oponível em qualquer processo de execução civil, fiscal, previdenciária, trabalhista ou de outra natureza, salvo se movido por: [...] por obrigação decorrente de fiança concedida em contrato de locação.

${ }^{36}$ VENOSA, Sílvio de Salvo. Lei do inquilinato comentada: doutrina e prática: Lei 8.245, de 18.10.1991. 8. ed., São Paulo: Atlas, 2005, p. 372.
} 
ainda que seja o único bem imóvel que possui, é passível de penhora no caso de dívida oriunda de contrato de locação. ${ }^{37}$

A constitucionalidade desse dispositivo legal começou a ser questionada de maneira mais intensa a partir da Emenda Constitucional $n^{\circ} 26$, de 14.02 .2000 , que incluiu, no art. $6^{\circ}$ da Constituição Federal, o "direito à moradia" no rol dos direitos sociais, trazendo consigo a discussão sobre este inciso estar violando um direito fundamental, isto é, o direito à moradia. O Ministro Carlos Velloso do Supremo Tribunal Federal, em decisão monocrática, julgou o RE 352940 - SP, referindo que "o direito à moradia é um direito fundamental de $2^{\mathrm{a}}$ geração, daí porque o bem de família de um indivíduo não estaria sujeito à penhorabilidade”... ${ }^{38}$

Contudo, em 08 de fevereiro de 2006 o Supremo Tribunal Federal retomou a discussão da questão envolvendo a constitucionalidade da penhora do bem de família do fiador, motivada pela Emenda Constitucional $n^{\circ} 26$ de 2000, que inseriu o direito à moradia no rol dos direitos sociais no art. $6^{\circ}$ da Constituição Federal. Nessa sessão, foi julgado o RE 407.688/SP, em Sessão Plenária ${ }^{39}$, tendo como Presidente o Ministro Nelson Jobim e como relator o Ministro Cezar Peluso, que entendeu como constitucional o inciso VII do art. $3^{\circ}$ da Lei ${ }^{\circ}$ 8.009/90. O Ministro Eros Grau, em voto divergente, acrescentou que, ao sustentar o direito à moradia como um direito social, o fazia no sentido de tutelar a moradia não apenas do proprietário do imóvel, mas também o direito à moradia de forma geral, ou seja, o direito à moradia até daquele que não é proprietário de algum imóvel. No seu entender, restringir o conceito do direito à moradia iria diminuir ainda mais o acesso de muitas pessoas ao mercado de moradia e que no Brasil são poucos os proprietários de imóvel, ao passo que grande é o número daqueles que não o são ${ }^{40}$. O Ministro Joaquim Barbosa manifestou em seu voto que a violação ao direito fundamental deu-se numa relação jurídica entre privados e não entre o titular do direito e o Estado, surgindo com isso a pergunta: "saber se esses direitos se impõem, com a mesma força e mesmo alcance, às relações travadas ao largo de qualquer manifestação estatal”. E também é necessário decidir, com o auxílio de “um juízo de ponderação, qual dos direitos devem preponderar", ${ }^{41}$

Atualmente, o Judiciário tem servido de "prestador de serviço para uma classe social, ou um grupo social” que busca a solução dos conflitos no judiciário e que se assemelha cada vez mais a uma justiça privada, "de submissão pura e simples dos mais fracos, menos espertos ou menos ricos”. Ao falar em menos ricos, pode-se

37 VASCONCELOS, Rita de Cássia Corrêa de. A impenhorabilidade do bem de família: e as novas entidades familiares. São Paulo: Editora Revista dos Tribunais, 2002. - (Coleção estudos de direito de processo Enrico Túlio Liebman; v. 51, p. 73).

${ }^{38}$ REINALDO FILHO, Demócrito. Bem de Família do Fiador de Locação Pode Ser Penhorado - A Nova Decisão do STF. In: Revista IOB de Direito Civil e Processual Civil, ano VII, nº 40, Mar-abr de 2006, p. 8/9.

${ }^{39}$ BRASIL. Supremo Tribunal Federal. RE 407.688/SP. Rel. Min. Cezar Peluso, DJ 6.10.2006.

${ }^{40}$ Parcela do voto do Ministro Eros Grau, que divergiu do voto do Relator Min. Cezar Peluso. (BRASIL. Supremo Tribunal Federal. RE 40.7688 / SP. Rel. Min. Cezar Peluso, DJ 6.10.2006).

${ }^{41}$ Entendimento e parcela do voto do Ministro Joaquim Barbosa, ao concordar com o relator Ministro Cezar Peluso. (BRASIL. Supremo Tribunal Federal. RE 40.7688 / SP. Rel. Min. Cezar Peluso, DJ 6.10.2006). 
exemplificar aqueles enfraquecidos pela perda de capital, valores ou obrigações que esperavam terem sido cumpridas nas relações contratuais. ${ }^{42}$

A justiça "das trocas diz-se comutativa, ou retributiva ou corretiva", em que “comutar é trocar, retribuir é devolver e corrigir é restaurar ao estado certo (e anterior)". Deve-se enfatizar que há regras para regular as trocas, para a redistribuição e regras para a correção. Essas regras para a troca estão estabelecidas nas relações bilaterais. ${ }^{43}$

A violação dessas regras promove uma busca no Judiciário para a solução do conflito resultante, de infração contratual motivada por inadimplemento dos valores relativos ao aluguel. Como direito constitucionalmente garantido ao indivíduo é dado o direito de buscar no Judiciário a solução para todos os litígios ${ }^{44}$. Ao locador é dado o direito de, através do fundamento da justiça comutativa que se resume na prestação jurisdicional, receber aquilo que lhe é devido em decorrência do contrato de locação de imóvel.

Assim, a justiça comutativa ${ }^{45}$ fundamenta a aplicação da regra ${ }^{46}$ que ordena a penhora do bem de família do fiador da locação e como princípio ${ }^{47}$ que regula no

\footnotetext{
${ }^{42}$ LOPES, José Reinaldo de Lima. Direitos sociais, p. 129. Importante comentar que, nesse caso, o autor se refere às relações de consumo. Em outra situação, refere-se à impunidade dos “poderosos, ricos ou maioria dominante". 43 LOPES, José Reinaldo de Lima. Direitos sociais, p. 145. Montoro escreve sobre o contrato que, "o homem, essencialmente livre, depende apenas de si mesmo; não pode, por isso, ser sujeito a outras leis, senão àquelas que ele consentiu, seja a lei particular, que decorre do acordo de vontade entre indivíduos o contrato -, seja a lei do Estado, decorrente do ‘contrato social'”. (MONTORO, André Franco. Introdução à Ciência do Direito, p. 162). Nesse mesmo sentido, Dresch escreve que, "assim, a justiça corretiva opera nas transações entre seres humanos em que não há uma relação de subordinação decorrente da presença de um ente distribuidor. Enfoca tal sentido de justiça a correção nas relações estabelecidas entre os indivíduos de dada comunidade, através da busca do equilíbrio nas relações privadas, voluntárias (trocas) e involuntárias (ilícitos)”. (DRESCH, Rafael de Freitas Valle. A influência da economia na responsabilidade civil. In: Direito e Economia. Organizador Luciano Benetti Timm. São Paulo: 2005, p. 130).

${ }^{44}$ Art. 5, inciso XXXVI da Constituição Federal: A lei não excluirá da apreciação do Poder Judiciário lesão ou ameaça a direito.

45 “Quando da aplicação da análise da justiça corretiva, é necessário que se apresente uma relação entre indivíduos na qual um deles atue tomando mais dos bens do que lhe cabe e, nessa senda, ganhando indevidamente e acarretando que o outro perca indevidamente. Nessa situação, a justiça corretiva determina uma correção de maneira a restabelecer a igualdade perdida. Tal relação entre ganho indevido de um sujeito da relação e perda indevida de outro sujeito da relação é que deve ser sanada para que se estabeleça a justiça corretiva. A justiça corretiva, por conseguinte, é o mecanismo que objetiva o equilíbrio entre ganhos e perdas correspondentes numa relação entre seres humanos”. (DRESCH, Rafael de Freitas Valle. Fundamentos da responsabilidade civil pelo fato do produto e do serviço no direito brasileiro: um debate jurídico-filosófico entre o formalismo e o funcionalismo no direito privado. Porto Alegre: UFRGS, 2005. Dissertação (Mestrado em Direito), Faculdade de Direito, Universidade do Rio Grande do Sul, 2005, p. 45).

${ }^{46}$ As regras são normas que, "verificados determinados pressupostos, exigem, proíbem ou permitem algo em termos definitivos, sem qualquer excepção (direito definitivo)”... (CANOTILHO, José Joaquim Gomes. Direito constitucional. 5. ed. Coimbra: Livraria Almedina, 1997, p. 1239).

${ }^{47}$ Os princípios são normas que ordenam algo que será realizado na medida do possível, de acordo com as possibilidades jurídicas e reais existentes. (ALEXY, Robert. Teoria de los derechos fundamentales. Madrid: Centro de Estudios Constitucionales, 1991, p. 82/6). Humberto Ávila ressalta que, segundo Alexy, a distinção entre princípios e regras não pode ser fundada no modo tudo ou nada de aplicação proposto por Dworkin, mas deve resumir-se a dois fatores: diferença quanto à colisão, no sentido de que os princípios em colisão encontram-se limitados normativamente de forma recíproca, ao passo que as regras em colisão têm a solução do conflito na declaração de invalidade de uma das regras ou com a inclusão de uma exceção que vai resolver o conflito; diferença quanto à obrigação que instituem, no sentido de que as
} 
Judiciário a atividade dos privados na busca pela justiça aplicada, in casu, às relações contratuais.

Por outro lado, no ordenamento jurídico brasileiro, o princípio da dignidade da pessoa humana ${ }^{48}$ foi positivado na Constituição Federal de 1988, junto ao art. $1^{\circ}$, inciso III, que o elencou como fundamento do Estado democrático de Direito, em que "reconheceu expressamente que é o Estado que existe em função da pessoa humana, e não o contrário, já que o homem constitui a finalidade precípua, e não o meio da atividade estatal”. ${ }^{49}$

A ideia da dignidade da pessoa humana estabelece o ser humano como tendo um valor próprio que lhe é inerente, absoluto, distinguindo-o das outras criaturas. O homem, como ser livre, é dono do seu destino e responsável pelos seus atos e a qualidade interior de pessoa humana atualmente denominada como dignidade, "é algo que se reconhece, respeita e protege, mas não possa ser criado ou lhe possa ser retirado, já que existe em cada ser humano como algo que lhe é inerente”. ${ }^{0}$

Cabe ao Estado a tarefa de guiar as ações no sentido de preservar a dignidade existente e criar condições que promovam o exercício pleno da dignidade dos indivíduos para que possam realizar, na medida do possível, de forma parcial, ou totalmente, eles próprios as suas necessidades existenciais básicas, garantir uma vida digna, um ideal a ser promovido pelo próprio Estado. ${ }^{51}$

Uma outra dimensão dada à dignidade da pessoa humana consiste nas condições adequadas de vida e subsistência do indivíduo e da sua família, no sentido de moradia, alimentação, educação, saúde, lazer, vestuário, higiene, Transporte e Previdência Social, como bens a suprir as suas necessidades básicas, expressas no art. $7^{\circ}$, inciso IV da Constituição Federal de $1988 .^{52}$

regras instituem obrigações absolutas, que não são superadas pelas regras opostas, ao passo que os princípios instituem obrigações prima facie, ou seja, existe a possibilidade de essas obrigações serem superadas ou derrogadas na colisão com outros princípios. (ÁVILA, Humberto. Teoria dos Princípios, da definição à aplicação dos princípios jurídicos. 5. ed. São Paulo: Malheiros, 2006, p. 38).

${ }^{48}$ A Declaração Universal das Nações Unidas (1948), em seu art. $1^{\circ}$, dispõe que: Todos os seres humanos nascem livres e iguais em dignidade e direitos. Dotados de razão e consciência, devem agir uns para com os outros em espírito e fraternidade. Disponível em <http://www.direitoshumanos.usp.br/counter/Onu/ Sist_glob_trat /texto/texto_1.html > Acesso em 12 out. 2007.

49 SARLET, Ingo Wolfgang. A eficácia dos direitos fundamentais... 2. ed. rev. atual. Porto Alegre: Livraria do Advogado, 2001, p. 103.

${ }^{50}$ SARLET, Ingo Wolfgang. A eficácia dos direitos fundamentais, p. 106.

${ }^{51}$ Segundo Luis Fernando Barzotto, o conceito de dignidade na sociedade democrática, parte do princípio da justiça social, "fundada em uma legalidade que afirma a igualdade de todos os seres humanos como membros iguais da sociedade. Como a lei impõe direitos e deveres iguais para todos, a justiça legal torna-se justiça social, aquela em que todo membro da sociedade vale tanto como qualquer outro, e todo ato em conformidade com a lei redunda, beneficia igualmente a todos. [...] A justiça social considera o ser humano simplesmente na sua condição de pessoa humana, nos seus direitos e deveres humanos.[...] para a justiça social, os seres humanos, considerados como pessoas, são iguais e, portanto, toda desigualdade em aspectos constitutivos da pessoa, como é o caso das suas necessidades materiais básicas, deve ser afastada”. (BARZOTTO, Luis Fernando. Justiça Social. Gênese, estrutura e aplicação de um conceito. Disponível em <http://www.planalto.gov.br/ccivil_03/revista/Rev_48 /Artigos/ART_LUIS.htm> Acesso em: 4 fev. 2007).

${ }^{52}$ Menke frisa que, "a família foi textualmente referida como instituição objeto de proteção, o que se vê reforçado pela disposição do $\S 7^{\circ}$, art. 226, também da CF. Além desses bens, outros igualmente previstos na Constituição [...] acesso à justiça (art. 5 $\mathrm{XXXV}, \mathrm{CF}$ ), da manutenção da integridade física, da preservação da intimidade [...] ." (MENKE, Cassiano. A proibição aos efeitos de confisco no Direito Tributário, p. 102). 
O princípio da dignidade da pessoa humana estabelece uma vinculação com outros princípios fundamentais, de forma que não há como dissociá-los. Não é possível abstrair a liberdade e a igualdade da dignidade da pessoa humana ${ }^{53}$. Esses princípios se encontram como que vinculados entre si, formando um manto de proteção notável dos direitos fundamentais do indivíduo, protegendo a sua liberdade pessoal e a isonomia. O direito à vida e à integridade física e corporal, o direito à proteção da intimidade e da esfera privada dos indivíduos são garantias específicas da dignidade da pessoa humana. ${ }^{54}$

Sarlet conceitua a dignidade da pessoa humana como segue:

[...] a qualidade intrínseca e distintiva de cada ser humano que o faz merecedor do mesmo respeito e consideração por parte do Estado e da comunidade, implicando, neste sentido, um complexo de direitos e deveres fundamentais que assegurem a pessoa tanto contra todo e qualquer ato de cunho degradante e desumano, como venham a lhe garantir as condições existenciais mínimas para uma vida saudável, além de propiciar e promover sua participação ativa e co-responsável nos destinos da própria existência e da vida em comunhão com os demais seres humanos. ${ }^{55}$ (grifo no original)

Acrescenta-se que, na forma como foi positivada a dignidade da pessoa humana no art. $1^{\circ}$, inciso III da Constituição Federal de 1988, ela assume a condição de princípio fundamental, visto que "é norma(s) definidora(s) de direitos, mas também de deveres fundamentais". 56

Quando se fala em direito à dignidade humana, na realidade está se considerando “o direito a reconhecimento, respeito, proteção e até mesmo promoção e desenvolvimento da dignidade, podendo inclusive falar-se de um direito a uma existência digna”, sem ofender outros sentidos que se possa dar aos direitos fundamentais referentes à dignidade da pessoa. Na qualidade de princípio fundamental, o princípio da dignidade da pessoa humana constitui um "valor-guia” de todo ordenamento jurídico, não se restringindo apenas aos direitos fundamentais ${ }^{57}$, sendo caracterizado dessa forma “como o princípio

\footnotetext{
${ }^{53}$ Relembrando o ensinamento de Aristóteles sobre a igualdade, o fato de que ela segue um critério de proporção aritmética, não importando a qualidade dos indivíduos. (ARISTÓTELES. Ética a Nicômacos. 4. ed., tradução de Mário da Gama Kury. Brasília: Editora Universidade de Brasília, 2001, p. 97-98). Menke escreve a respeito da igualdade no princípio da dignidade da pessoa humana dizendo que sendo igualdade básica e absoluta, “[...] é preciso dar a todos a mesma coisa para que se garanta a justiça social”. (MENKE, Cassiano. A proibição aos efeitos de confisco no Direito Tributário, p. 104).

${ }^{54}$ SARLET, Ingo Wolfgang. A eficácia dos direitos fundamentais, p. 115.

${ }^{55}$ SARLET, Ingo Wolfgang. Dignidade da pessoa humana e direitos fundamentais na Constituição Federal de 1988. 2. ed.rev. ampl. Porto Alegre: Livraria do Advogado, 2002, p. 62.

${ }^{56}$ SARLET, Ingo Wolfgang. Dignidade da pessoa humana ..., p. 72.

${ }^{57}$ Dresch escreve que, “[...] a dignidade denota que a legislação ideal expressa na filosofia kantiana não pode admitir - assim como a aristotélica [...] , que as determinações da legislação prejudiquem uma pessoa em favor de outras, ou ainda, que prejudiquem uma minoria em favor do bem da maioria.[...] A legislação puramente racional, na doutrina de Kant, não admite imperativos hipotéticos que poderiam sujeitar determinadas pessoas a servirem de meio para quaisquer fins contingentes de uma maioria. [...] Da concepção de dignidade da pessoa humana, é preciso destacar ainda o princípio da autonomia da vontade como proposto por Kant, eis que este fundamenta a dignidade humana na autonomia da vontade. [...] Portanto, todo o ser
} 
constitucional de maior hierarquia axiológico-valorativa”. ${ }^{58}$

Na condição de valor e de princípio fundamental normativo, a dignidade da pessoa humana traz para si como um ímã o conteúdo de todos os direitos fundamentais, exigindo e reconhecendo proteção a todos eles, em todas as gerações. À medida que se negam à pessoa humana os direitos fundamentais que lhe são imanentes, está se negando a sua própria dignidade.

Com fundamento no princípio da dignidade da pessoa humana, são reconhecidos pela Constituição Federal direitos como o de personalidade jurídica ${ }^{59}$ a todos os seres humanos e também o direito de igualdade garantindo que todos os seres humanos são iguais em dignidade e direitos. ${ }^{60}$

A dignidade da pessoa humana fundamenta o direito à moradia inserido na Constituição Federal no art. $6^{\circ}$, ocupando, juntamente com outros, o rol dos direitos sociais e identificados como direitos de segunda geração e, segundo Sarlet, o direito à moradia não significa "necessariamente um direito à moradia própria e, portanto, não pode ser identificado (apesar das conexões evidentes) com o direito de propriedade". ${ }^{61}$

Assim como os direitos sociais, econômicos e culturais, o direito à moradia na sua condição de direito de cunho prestacional, como prestações negativas na forma de defesa e positivas na forma de programas de assistência, segundo Sarlet, encontram-se a serviço "da igualdade e da liberdade material, objetivando, em última análise, a proteção da pessoa humana contra as necessidades de ordem material e a garantia de uma existência com dignidade”. ${ }^{6}$

humano, por ser dotado de uma vontade autônoma, tem um valor incondicional e, de tal sorte, não pode ser funcionalizado (servir de meio para fins outros)". (DRESCH, Rafael de Freitas Valle. Fundamentos da responsabilidade civil pelo fato do produto e do serviço... , p. 58/9).

${ }^{58}$ SARLET, Ingo Wolfgang. Dignidade da pessoa humana ...., p. 73/4.

${ }^{59}$ Caio Mário ressalta que a idéia de personalidade está ligada de forma íntima à de pessoa, “pois exprime a aptidão genérica para adquirir direitos e contrair deveres. Esta aptidão é reconhecida a todo ser humano, o que exprime uma conquista da civilização jurídica. [...] Como o homem é o sujeito das relações jurídicas, e a personalidade a faculdade a ele reconhecida, diz-se que todo homem é dotado de personalidade. [...] A personalidade, como atributo da pessoa humana, está a ela indissoluvelmente ligada. Sua duração é a vida. Desde que vive e enquanto vive, o homem é dotado de personalidade. (PEREIRA, caio Mário da Silva. Instituições de Direito Civil. Vol. I. Introdução ao direito civil; teoria geral do direito civil. 20. ed. rev. e atual. por Maria Celina Bodin de Moraes. Rio de Janeiro: Forense, 2004, p. 213 et seq.).

${ }^{60}$ Artigo $1^{\circ}$ da Declaração Universal das Nações Unidas (1948).

${ }^{61}$ SARLET, Ingo Wolfgang. Dignidade da pessoa humana ..., p. 94. Sarlet escreve ainda que, apesar de a propriedade servir de moradia ao indivíduo titular desse direito, o direito à moradia é diferente do direito de propriedade mesmo no caso em que serve de pressuposto para aquisição do domínio por usucapião, "atuando, ainda, com indicativo da aplicação da função social da propriedade, [...] o direito à moradia convém frisá-lo - é direito fundamental autônomo, com âmbito de proteção e objetos próprios”. (SARLET, Ingo Wolfgang. O direito Fundamental à moradia ..., p. 211 et seq.).

${ }^{62}$ SARLET, Ingo Wolfgang. Dignidade da pessoa humana ..., p. 95. Nesse mesmo sentido, Souza escreve que "estando presentes os fundamentos do direito à moradia como tal e o dever do Estado brasileiro em promover e proteger, por meio de medidas legislativas, políticas progressivas de desenvolvimento do setor habitacional no país”. (SOUZA, Sérgio Iglesias Nunes de. Direito à moradia e de habitação, p. 260).

DiREITOS Fundamentais $\mathcal{E}$ JustiÇA N 7 - ABR./JUn. 2009 
4. OS ARGUMENTOS CENTRAIS DA DECISÃO DO SUPREMO TRIBUNAL FEDERAL

\subsection{O Argumento Voluntarista}

Sabidamente, a justiça corretiva - ou comutativa como a define Tomás de Aquino -, que explicita, conforme o formalismo, a ideia central do caráter das relações de direito privado, é pensada nos termos de igualdade absoluta (ou aritmética segundo Aristóteles). As características dos seres humanos são absolutamente abstraídas e, de tal sorte, eles são tomados a revelia de suas qualidades, sem qualquer diferenciação numa relação. A relação é pensada não nas distribuições, mas nas transações como delimita Aristóteles.

De tal sorte, na justiça corretiva, há sempre uma relação entre indivíduos que foi desequilibrada e deve, nestes termos, ter o equilíbrio restabelecido ${ }^{63}$. A relação jurídica objeto da justiça corretiva é aquela que se estabelece nas transações voluntárias (negócios jurídicos) e involuntárias (responsabilidade civil e enriquecimento sem causa). ${ }^{64}$

Assim, a justiça corretiva opera nas transações entre seres humanos em que não há uma relação de subordinação decorrente da presença de um ente distribuidor. Enfoca, tal sentido da justiça, a correção nas relações estabelecidas entre os indivíduos de dada comunidade, através da busca do equilíbrio nas relações privadas.

Quando da análise de uma relação centrada na justiça corretiva é necessário que essa relação se estabeleça entre indivíduos, um deles atue tomando mais dos bens do que lhe cabe, ganhando, assim, indevidamente e, por via de consequência, acarretando que o outro perca indevidamente.

Tal relação entre ganho indevido de um sujeito da relação e perda indevida de outro sujeito da relação é que deve ser sanada para que se estabeleça a justiça corretiva. A justiça corretiva, por conseguinte, funciona como um mecanismo de equilíbrio entre ganhos e perdas correspondentes numa relação entre seres humanos.

Para que tal mecanismo se efetive, portanto, é necessário que o ganho indevido seja retirado do sujeito que agiu causando o desequilíbrio e entregue ao sujeito que sofreu a perda indevida. Havendo, nesses termos, uma necessária correlação entre o ganho a ser retirado e a perda a ser reparada. Mister destacar, todavia, que esta relação de retirada do ganho de um devedor e entrega ao credor não se trata de pagar o mal com o mal. A reciprocidade necessária, como bem destaca Tomás de Aquino, consiste no restituir o que foi retirado do credor indevidamente, ou seja, no colocar o credor no estado anterior ao ato indevido ${ }^{65} 66$.

${ }^{63}$ TUGENDHAT, p. 396

${ }^{64}$ TOMÁS DE AQUINO é esclarecedor ao analisar as transações voluntárias e involuntárias: "En todas las acciones de este género, ya voluntarias, ya involuntarias, existe un mismo módulo para determinar el término medio, según la igualdad de la compensación, y por esto todas estas acciones pertenecen a una sola especie de justicia, es decir, la conmutativa.” (Suma Teológica, II - II, q. 61, a. 3).

${ }^{65}$ Assim esclarece TOMÁs DE AQUINO: "Pero, en todos estos casos, debe hacerse, según la naturaleza de la justicia conmutativa, la compensación conforme a la igualdad, es decir, de modo que la reacción sea igual a la acción. Pero no tendría lugar siempre esa igualdad si alguien experimentase la misma especie de mal que a su vez hizo, porque, en primer lugar, cuando uno ofende injuriosamente a la persona de otro de más alta categoría, es mayor la acción que la pena de la misma especie que él habría de padecer en 
Nesse sentido, há a presença de um ente corretor, responsável pelo restabelecimento do equilíbrio entre ganhos e perdas. Tal ente é o juiz que, diante de um ato praticado por um devedor e sofrido por um credor numa obrigação (incumprimento de uma prestação, por exemplo), busca restabelecer o equilíbrio tirando o ganho indevido do devedor e entregando ao credor.

O cerne da justiça corretiva - diferentemente da justiça distributiva que se dá na divisão igual em distribuições, como será analisado no ponto infra - é a divisão igual em transações. Contudo, como já destacado quando da demonstração da diferença da denominação dada a esta espécie de justiça por Tomás de Aquino e Aristóteles justiça comutativa para o primeiro e justiça corretiva para o segundo -, há dois aspectos centrais no tratamento desse sentido da justiça. Um aspecto que enfatiza o caráter comutativo das trocas voluntárias, mais especificamente a necessária reciprocidade entre prestação e contraprestação nas transações e, outro aspecto que enfatiza o caráter corretivo quando de uma conduta que viole o equilíbrio na relação entre indivíduos.

Destarte, mesmo considerando a diferença, inclusive, na denominação utilizada por cada filósofo, reitera-se que ambos tratam do mesmo sentido de justiça, mas com enfoques distintos, pois enquanto Aristóteles centra sua análise na patologia (correção), Tomás de Aquino enfatiza a própria essência da transação - reciprocidade entre prestação e contraprestação nas trocas - o que denomina-se no direito dos contratos, por influência romana, de sinalagma ou causa sinalagmática ${ }^{67}$.

Contudo, considerando que o presente trabalho objetiva a análise do instituto jurídico da fiança quando do inadimplemento da obrigação do locatário, deve ser ressaltado o citado caráter corretivo da análise da justiça corretiva/comutativa, vez que a necessidade de penhora do bem de família do fiador está intrinsecamente vinculada à ocorrência de um inadimplemento de uma obrigação e a necessidade de correção, elementos centrais do aspecto corretivo da justiça em comento.

De tal sorte, é precisamente na necessidade de correção quando da ocorrência do inadimplemento que se torna evidente a busca do conhecimento da forma vinculada ao fim imediato. A forma defendida pelo formalismo está justamente centrada na análise da justiça corretiva. Qual seria está forma numa relação jurídica contratual?

Para o formalismo, nos termos da justiça corretiva, a forma é definida pelo citado mecanismo de ressarcimento da perda sofrida indevidamente pelo credor através de retirada do ganho obtido indevidamente pelo devedor como objetivo imediato

retribución (...). Tampoco, asimismo, en las transacciones voluntarias la retribución sería siempre igual si uno diera cosa suya recibiendo la de otro, porque tal vez ésta sea mucho mayor que la suya. Por eso es preciso en los cambios igualar la contraprestación a la acción, según cierta medida proporcional, por lo cual se inventaron las monedas. De este modo, la reciprocidad en las prestaciones es lo justo conmutativo." (Suma Teológica, II - II, q. 61, a. 4).

${ }^{66}$ Nesse sentido é bem explicita LE GAC-PECH, p. 33: "La justice corrective est celle de la sanction réparatrice, celle qui directement ou par compensation rétablit le statut quo ante.”.

${ }_{67}$ Nesse sentido, tratando da causa sinalagmática no direito contratual profícua a tese de doutorado de FERREIRA DA SILVA, Luis Renato: “Com tudo isto, pode-se ver que a noção de causa sinalagmática, como se apresenta nesta tese é tributária dos conceitos supra referidos da teoria aristotélica. A importância que o direito atribui a várias situações jurídicas concretas, sempre precisando esta compensação por "perdas" e "ganhos" parece ser a justificativa ...". 
de uma relação no sentido de garantia dos objetivos contratuais (cumprimento das prestações e indenização por perdas e danos). A penhora do bem de família, portanto, serve como instrumento para essa retirada do ganho indevido do devedor e entrega ao credor.

Assim, o formalismo tem as características centrais da relação contratual, nos termos da justiça corretiva, como sendo: 1 . O cumprimento das obrigações como fim; 2. A correlatividade entre dever e direito nos termos do vínculo obrigacional e: 3. A intencionalidade, decorrente da personalidade, como fundamento da obrigação contratual.

No que refere ao presente estudo, cumpre analisar o conceito essencial destacado pelo formalismo para completar a ideia da justiça corretiva, qual seja, o conceito de personalidade. O conceito de personalidade é herdado do pensamento kantiano: a personalidade como capacidade intencional decorrente do arbítrio livre, sem consideração às qualidades particulares ${ }^{68}$. Por conseguinte, define-se a concepção da pessoa que fundamenta o direito ${ }^{69}$. Esta concepção abstrata do ser humano é o que a tradição do direito natural chamou "personalidade” justamente com base nos textos legais romanos antigos que usam “a pessoa” quando discutem a posição legal do indivíduo $^{70}$. A personalidade, para o formalismo, contém efetivamente o que o ser humano tem de essencial, sua liberdade (fundada na racionalidade) consubstanciada na sua capacidade intencional.

Contudo, o que é olvidado no argumento voluntarista dos ministros do Supremo Tribunal Federal é que essa liberdade, que vincula o indivíduo pela intencionalidade nos termos da justiça corretiva, pelo seu fundamento racional, depende do respeito à dignidade da pessoa humana. Como salienta Kant, o pensador de referência para os voluntaristas, pela segunda formulação do imperativo categórico, a ação racional está sempre ligada ao uso que se faz dos seres humanos, eis que, segundo Kant:

“aquilo porém que constitui a condição só graças à qual qualquer coisa pode ser um fim em si mesma, não tem somente um valor relativo, isto é um preço, mas um valor íntimo, isto é dignidade.”71

\footnotetext{
${ }^{68}$ Ver especificamente: WEINRIB, Correlativity, Personality, and the Emerging Consensus on Corrective Justice, pp. 13/15.

${ }^{69}$ Kant assim preceitua na sua obra A Metafísica dos Costumes, pp. 38/39: “em esta relación recíproca del arbitrio no se atiende em absoluto a la materia del arbitrio, es decir, al fin que cada qual se proponecon el objeto que quiere, por ejemplo, no se pregunta si alguien puede beneficiarse tambien o no de la mercancia que me compra para su proprio negocio; sino que se pregunta por la forma em la relación del arbitrio de amdas partes, em la medida que se considera unicamente como libre, y si como ello, la acción de uno de ambos puede conciliarse com la liberdad del outro según uma ley universal”.

${ }^{70}$ É importante destacar as conclusões de Marcos de Campos LUDWIG sobre a relação entre as noções de personalidade e de pessoa: “a) a noção de personalidade não tem raiz idêntica ao conceito jurídico de pessoa. Enquanto este tem origem remota e experimentou um longo e inconstante processo de desenvolvimento histórico, a personalidade nasceu como uma definição essencialmente ética e foi, num momento posterior, recepcionada e adequada pelo direito; b) nesse sentido, sob o influxo racionalista das idéias iluministas, a laicização da personalidade representou uma notável conquista da doutrina jurídica, tendo como fecho teórico a vinculação da liberdade humana à Moral, empreendida de forma definitiva por Kant; ...” (O Direito ao livre desenvolvimento da personalidade na Alemanha e possibilidades de sua aplicação no direito privado brasileiro. In: A reconstrução do Direito Privado, Judith Martins-Costa (org.), RT, São Paulo: 2002, p. 301. ${ }^{71}$ Kant, A Metafísica..., p. 77.
} 
Nesse aspecto, a dignidade ${ }^{72}$ denota que a legislação ideal expressa na filosofia kantiana não pode admitir que as determinações da legislação positiva prejudiquem um ser humano em favor de objetivos hipotéticos. A legislação puramente racional, na doutrina de Kant, não admite imperativos hipotéticos que poderiam sujeitar determinadas pessoas a servirem de meio para quaisquer fins contingentes de uma maioria ou dela própria. Para bem ilustrar essa concepção de suma importância, vale destacar as palavras de Kant:

“A necessidade prática de agir segundo este princípio, isto é, o dever, não assenta em sentimentos, impulsos e inclinações, mas sim somente nas relações dos seres racionais entre si, relação essa em que a vontade de um ser racional tem de ser considerada sempre e simultaneamente como legisladora, porque de outra forma não podia pensar-se como fim em si mesmo. A razão relaciona pois cada máxima da vontade concebida como legisladora universal com todas as outras vontades e com todas as acções para conosco mesmos, e isto não em virtude de qualquer vantagem futura, mas em virtude da ideia da dignidade de um ser racional que não obedece a outra lei senão àquela que ele simultaneamente se dá.”73

Da concepção de dignidade da pessoa humana é preciso destacar ainda o princípio da autonomia da vontade como proposto por Kant, eis que este fundamenta a dignidade humana na autonomia da vontade ${ }^{74}$. Assim, autonomia da vontade é definida como "o conceito segundo o qual todo o ser racional deve considerar-se como legislador universal por todas as máximas de sua vontade para, deste ponto de vista, se julgar a si mesmo e às suas acções”,75. Portanto, todo o ser humano, por ser dotado de uma vontade autônoma, tem um valor incondicional e, de tal sorte, não pode ser funcionalizado (servir de meio para fins outros). Nesse contexto, o ser humano não pode, através do exercício do seu arbítrio, atentar contra a dignidade humana das demais pessoas e, também, da sua pessoa.

A autonomia da vontade kantiana legitima o arbítrio livre, ou seja, aquele arbítrio conforme a vontade que respeita o valor do ser humano. Toda a liberalidade (uso do arbítrio) que contrasta com o valor (dignidade) do ser humano, seja o valor humano nos outros ou em nós mesmos é contrária à razão e, portanto, ilegítima para consubstanciar uma obrigação.

${ }^{72}$ Cabe reiterar que a concepção de dignidade está presente no pensamento aristótelico como bem ensina Luis Fernando Barzotto: "Esta igualdade básica, absoluta, é uma igualdade na dignidade. Como foi visto acima, a dignidade é o conceito fundante da experiência jurídico-política contemporânea. A "dignidade da pessoa humana" é o termo que expressa o princípio subjacente à justiça social: a pessoa humana é digna, merecedora de todos os bens necessários para realizar-se como ser concreto, individual, racional e social. Ora, elencar os direitos e deveres derivados da mera condição de pessoa é assumir uma determinada concepção do que é a vida boa, a vida plenamente realizada para o ser humano. A comunidade fundada sobre a dignidade da pessoa humana é aquela em que há um consenso sobre uma determinada concepção de vida boa. Todos consideram a todos como sujeitos merecedores dos bens que integram a vida boa, apenas em virtude da sua condição de pessoas humanas.” (BARZOTTO, Justiça...).

${ }^{73}$ KANT, Fundamentação..., p. 77.

74 “A Autonomia é pois o fundamento da dignidade da natureza humana e de toda a natureza racional." (Ibidem, p. 79).

${ }^{75}$ Ibidem, p. 75

DIREITOS FundAMENTAIS E J JUSTIÇA N 7 -ABR./Jun. 2009 
Por conseguinte, o analisado mecanismo de reequilíbrio da justiça corretiva, que se aplica nos casos de ganho indevido configurado por inadimplemento de obrigações assumidas voluntariamente, somente pode ser pensado nas situações em que essas obrigações nascem de uma vontade condizente com a dignidade da pessoa humana e os direitos fundamentais que a materializam.

Nesse compasso, o argumento voluntarista usado pelos ministros do Supremo Tribunal Federal não condiz com o formalismo centrado na justiça corretiva, pois o fato de que o fiador se obriga voluntariamente, portanto, não legítima a possibilidade de que ele abra mão de sua dignidade e de seu direito à moradia, eis que o respeito à dignidade é premissa de qualquer obrigação jurídica em termos voluntaristas. Nesse sentido, cabe destacar os ensinamentos de Ingo Sarlet:

Por mais que se deva admitir que a própria liberdade contratual expressa uma manifestação da mesma dignidade da pessoa humana que serve de fundamento ao conteúdo existencial da propriedade, quando, por exemplo, serve de moradia ao seu titular, não se pode olvidar que a ordem jurídica impõe limites significativos à autonomia privada, especialmente quando se cuida de hipóteses de renúncia a direitos fundamentais. A própria alienação voluntária da integralidade do patrimônio, em havendo herdeiros necessários ou eventualmente outros interesses a serem tutelados encontra limites em determinadas circunstâncias. ${ }^{76}$

Caso o raciocínio voluntarista fosse defensável seria possível aos indivíduos oferecer outros bens em garantia de forma a dispor de seus direitos fundamentais. Seria possível oferecer a vida como garantia? O corpo? A liberdade? O Direito prevê formas de instituição de garantias e impõe o cumprimento das obrigações, mas, a efetivação dessas garantias e cumprimento das obrigações não se dá sem limites, caso contrário, deveríamos possibilitar garantias como a carne do corpo que Antônio, o mercador, oferece a Shylock, o agiota, na obra o Mercador de Veneza de William Shakespeare.

\subsection{O Argumento Utilitarista}

A teoria funcionalista é diametralmente oposta à formalista, pois as obrigações são entendidas como instrumentos funcionais na obtenção de objetivos econômicos e sociais. O pensamento em termos funcional trata os institutos jurídicos de direito privado como instrumentos na busca de objetivos considerados relevantes em termos sociais e econômicos. Ao fixar tais objetivos externos, a análise funcionalista acaba por terminar uma racionalidade não mais centrada na justiça corretiva, mas sim na justiça distributiva.

No caso sob análise, o argumento apresentado pelo Ministro Cezar Peluso, nitidamente se enquadra numa análise funcional, pois interpreta a possibilidade de penhora do bem de família do fiador como um instrumento de política pública sobre oferta de moradias por intermédio de contratos de locação. Assim, o instrumento da penhora é analisado na sua relação com o objetivo desenvolvimento do acesso à moradia.

${ }^{76}$ SARLET, Ingo Wolfgang. A eficácia e efetividade do direito à moradia na sua dimensão negativa (defensiva): análise crítica à luz de alguns exemplos. Texto cedido pelo autor. 
Ao assim proceder, o Ministro Cezar Peluso acaba por adentrar numa racionalidade explicitada nos moldes da justiça distributiva, pois garante a impenhorabilidade a uns - locatários ou devedores em geral - e não garante a outros (fiadores).

Nesse compasso, cumpre aqui ressaltar, que o justo meio aristotélico em se tratando de distribuições, é definido pela avaliação sobre méritos e necessidades, que irá refletir diretamente no modo de repartição. A avaliação dos méritos está, ainda, diretamente vinculada aos bens (ou encargos) e para que servem, segundo conceitos compartilhados pelo grupo no qual se realiza a distribuição ${ }^{77}$. Qualquer distribuição depende de uma dupla avaliação, portanto, uma avaliação dos méritos ou necessidades dos sujeitos passivos da distribuição (condições de evitar os riscos) e uma avaliação da utilidade dos bens ou encargos a serem distribuídos. A informação, tanto sobre as características dos sujeitos passivos, quanto sobre os bens e encargos é de essencial importância para que se defina o justo numa distribuição, pois só através do conhecimento da qualidade dos sujeitos e da utilidade dos encargos se poderá estabelecer a correspondência entre estes dois fatores (qualidade e utilidade) e assim definir o justo meio e a configuração da igualdade na repartição/distribuição.

A justiça distributiva, pelo exposto, está delimitada numa mediana a ser definida entre quatro termos de uma relação, sendo dois termos os sujeitos e os outros dois a máxima e a mínima quantidade de um bem ${ }^{78}$. Assim, a distribuição será justa quando atentar para mesma igualdade entre as porções dos encargos (como penhora de bens) e os sujeitos (com base na capacidade) ${ }^{79}$.

O justo, no sentido distributivo, por conseguinte, está dado pela igualdade na proporção entre os méritos, capacidades ou necessidades dos sujeitos da relação e a proporção entre os bens a serem distribuídos pelo sujeito ativo da distribuição. O sujeito passivo que tem maior mérito, capacidade ou necessidade deve receber maior parte dos encargos ou bens numa distribuição para que se atenda ao critério igualdade. Assim, os fiadores, que recebem um maior encargo no cumprimento das obrigações originadas pelos contratos de locação deveriam ter uma diferença em relação aos locatários - ou os devedores de maneira geral - que justificasse o maior encargo configurado pela penhorabilidade do seu bem de família. Ademais, nos termos da análise funcionalista, essa diferença que impõe um maior encargo deveria ter por consequência um ganho no objetivo de garantir moradia a um maior número de indivíduos (uma maior utilidade geral).

É interessante notar que a mesma quantidade - definidora da igualdade no pensamento aristotélico - não ocorre entres os bens ou encargos que cada sujeito passivo da distribuição recebe, mais sim a mesma quantidade entre capacidade/ mérito e encargos/bens ${ }^{80}$.

\footnotetext{
${ }^{77}$ WALZER, p. 6.

78 “A solução de direito se inscreve na forma de uma equação que manifesta a igualdade, não dos bens distribuídos, mas de duas relações estabelecidas entre pessoas e funções” VILLEY, pp. 77.

79 “Assim, o justo também envolve quatro termos, no mínimo, e a relação ou proporção entre os primeiro par de termos é idêntica àquela entre o segundo par, pois as duas linhas que representam os indivíduos e porções são divididas similarmente ...” ARISTÓTELES. Ética a Nicômaco, p. 142.

${ }^{80}$ É TOMÁS DE AQUINO que explicita esta relação: “De ahí que en la justicia distributiva no se determine
} 
A igualdade nas distribuições justas de encargos, portanto, significa a mesma quantidade entre o que cada é capaz de suportar e o que cada um recebe de encargo. A relação entre maior capacidade e maior encargo se justificaria, em termos funcionais de justiça distributiva, na busca de objetivos públicos como arrecadação de impostos, por exemplo, que implementam fixação de encargos tributários com base em critérios como a capacidade distributiva.

Assim, em termos funcionais, mais especificamente utilitaristas, a exceção prevista no art. $3^{\circ}$, VII da Lei do Bem de Família que estabelece penhorabilidade do bem de família do fiador se justificaria sob duas condições: 1) O fiador tem uma diferença de capacidade em relação aos devedores em geral e aos locatários em particular; 2) A finalidade a ser buscada é melhor atendida pelos fiadores em função dessa diferença.

As regras que estabelecem distribuições no funcionalismo utilitarista se estruturam de maneira a verificar as consequências desses atos. Assim, a regra considerada correta é aquela que maximiza a utilidade, nesse caso, a regra correta seria a que maximiza o bem moradia. Para determinar essa maximização é necessário um raciocínio consequencialista como ensina Will Kymplicka:

“Um atrativo distinto, mas relacionado, é o “consequencialismo” do utilitarismo... sua importância é que ele requer que verifiquemos se o ato ou procedimento em questão realmente faz algum bem identificável ou não.”81

Destarte, o argumento utilitarista do Ministro Cesar Peluso falha no teste do próprio utilitarismo, por dois motivos básicos:

1) Não demonstra quais seriam as consequências da penhora do bem de família do fiador no mercado de locação, Com efeito, não existe nenhum estudo do mercado que fundamente o argumento de que a penhora do bem de família do fiador irá aumentar o acesso à moradia através de locações. Assim como é possível supor que a regra aumentaria a oferta de moradias é, também, perfeitamente plausível defender que esta regra irá diminuir o número de pessoas dispostas a prestar fiança o que tornaria o acesso à moradia mais restrito. Como não existe nenhuma análise confiável nesse sentido, o argumento falha por falta de confiabilidade da análise das consequências da regra de penhora do bem de família.

2) Não demonstra a diferença da penhora do bem de família do fiador em relação à penhora do bem de família do locatário e dos devedores em geral para fins de maximização do acesso à moradia. Será que a penhora do bem de família do locatário não maximiza o acesso à moradia? Qual a diferença, em relação à maximização do acesso à moradia, entre a penhora do bem de família do fiador e do locatário?

el medio según la igualdad de cosa a cosa, sino según la proporción de las cosas a las personas, de tal suerte que en la medida que una persona exceda a otra, así también la cosa que se le dé a dicha persona exceda a la que se dé a la otra persona. Y por esto, dice el Filósofo, que tal medio es según la proporcionalidad geométrica.” (Suma Teológica, II - II, q. 61, a. 2).

${ }^{81}$ KYMLICKA, Will. Filosofia Política Contemporânea. Trad. Luís Carlos Borges, São Paulo: Martins Fontes, 2006, p. 13. 
Nos moldes supracitados, não há como admitir o argumento sob análise, pois não se sustenta na própria racionalidade do utilitarismo.

\section{A SOLUÇÃO PELA PROPORCIONALIDADE}

Como supra-analisado, haverá conflito entre dois princípios sempre quando se entender que a Constituição protege, de forma simultânea, dois valores ou bens em contradição no caso concreto.

O conflito ou colisão de direitos fundamentais é do tipo de caso que Dworkin chamaria de hard cases, ou seja, casos de difícil solução, casos em que a "decisão normativa final não é alcançada com uma simples interpretação e aplicação de normas”. São casos que geralmente dividem os julgadores $\overline{\bar{\prime}}$ e se constituem na maioria questões concernentes à matéria constitucional. ${ }^{82}$

Com o acesso ao Poder Judiciário, em razão do princípio da inafastabilidade do controle jurisdicional segundo o preceito Constitucional expresso no art. $5^{\circ}$, inciso XXXV, compete ao Poder Judiciário responder sempre que provocado, pronunciando-se sobre qualquer questão envolvendo direitos, através de mecanismos processuais adequados. ${ }^{83}$

Ocorrendo conflito de direitos fundamentais, in concreto verifica-se que um direito fundamental exercido por um titular restringe, afeta ou cria obstáculos ao exercício de um direito fundamental de outro titular ${ }^{84}$. Segundo Sarlet, numa relação jurídica envolvendo direitos fundamentais conflitantes, torna-se imperativo "o dever de proteção dos direitos fundamentais de todas as pessoas”, sempre observando, respeitando e preservando o "núcleo essencial ${ }^{85}$ de cada direito e os critérios impostos pelo princípio da proporcionalidade ${ }^{86}$, que por sua vez, sempre acaba por implicar

82 “Casos difíceis ou duvidosos são aqueles cuja decisão normativa final não é alcançada com uma simples interpretação e aplicação de normas. Isto é, não são casos passíveis de solução pela mera e imediata observância das normas. A solução não é a consequência de um imediato enquadramento normativo. Não há uma única solução correta possível. Cogita-se de alternativas. São situações que exigem complexa e refinadas técnicas de decisão.” (STEINMETZ, Wilson Antônio. Colisão de direitos fundamentais $e$ princípio da proporcionalidade... Porto Alegre: Livraria do Advogado, 2001, p. 68). Dworkin explica que segundo o positivismo, hard cases seriam situações em que não haveria regras prévias que incidissem sobre eles. (DWORKIN, Ronald. Levando os direitos a sério. São Paulo: Martins Fontes, 2002, p. 127 et seq.).

${ }^{83}$ STEINMETZ, Wilson Antônio. Colisão de direitos fundamentais..., p. 67 et seq.

${ }^{84}$ Canotilho divide a colisão de direitos fundamentais entre dois grupos: colisão de direitos entre vários titulares de direitos fundamentais (colisão autêntica) e colisão entre direitos fundamentais e bens jurídicos da comunidade e do Estado (colisão não autêntica). (CANOTILHO, José Joaquim Gomes. Direito Constitucional, p. 1.253).

85 "O núcleo essencial dos direitos fundamentais é aquele que demarca a zona central do conteúdo e que conta com a proteção mais intensa contra restrições. [...] Todos os bens que se encontram nesse conteúdo materialmente essencial à existência do direito são condições inafastáveis para que ele tenha serventia ao seu titular. [...] Quando se trata do “mínimo existencial, do mínimo ‘exento’, do mínimo vital e do mínimo 'subsistencial,' se está referindo a um conteúdo materialmente essencial que é próprio de cada direito fundamental”. (MENKE, Cassiano. A proibição aos efeitos de confisco no direito tributário, p. 54/5).

${ }^{86}$ O princípio da proporcionalidade ou como Humberto Ávila prefere chamar, o postulado da proporcionalidade, para ser operacionalizado precisa de uma relação de causalidade entre o meio e o fim, ou seja, a medida concreta adotada para a realização de um direito e a finalidade, como promoção de um estado de coisas desejado. O exame que deve ser feito consiste em responder a três questões fundamentais relacionadas à adequação, à necessidade e à proporcionalidade em sentido estrito.(ÁVILA, Humberto. Teoria dos Princípios, p. 149). O ministro Gilmar Mendes, em julgado do BRASIL. Supremo Tribunal Federal, IF $n^{\circ} 164-1$ - SP, 
uma ponderação de bens ${ }^{87}$ ou interesses”... Nestes casos o princípio da dignidade da pessoa humana, juntamente com o direito à moradia como direito conexo, toma sobre si “como critério de solução, privilegiando-se [...] a opção (e, também a interpretação) mais favorável à dignidade da pessoa humana". ${ }^{88}$

\subsection{A análise do conflito existente entre a regra da penhora e o princípio da dignidade da pessoa humana}

O conflito entre a regra que determina a penhora do bem de família do fiador e o princípio da dignidade da pessoa humana é aparente, pois, na realidade, o conflito existente nesse caso é entre dois princípios. ${ }^{89}$

DJ 14.11.2003, esclareceu em seu voto que Alexy chama esse princípio de "a máxima da proporcionalidade” e que "coincide igualmente com o chamado núcleo essencial dos direito fundamentais [...]. Nesse sentido, o princípio ou máxima da proporcionalidade determina o limite último da possibilidade de restrição legítima de determinado direito fundamental”. Paulo Bonavides escreve que "a vinculação do princípio da proporcionalidade ao Direito Constitucional ocorre por via dos direitos fundamentais. É aí que ele ganha extrema importância e aufere um prestígio e difusão tão larga quanto outros princípios cardeais e afins, nomeadamente o princípio da igualdade. Protegendo, pois, a liberdade, ou seja, amparando direitos fundamentais, o princípio da proporcionalidade entende principalmente, [...], com o problema da limitação do poder legítimo, devendo fornecer o critério das limitações à liberdade individual”. (BONAVIDES, Paulo. Curso de Direito Constitucional. 11. ed. São Paulo: Malheiros, 2001, p. 359).

${ }^{87}$ Ávila se manifesta dizendo que "o postulado da proporcionalidade não se identifica com o da ponderação de bens; esse último exige a atribuição de uma dimensão de importância a valores que se imbricam, sem que contenha qualquer determinação quanto ao modo como deve ser feita essa ponderação, ao passo que o postulado da proporcionalidade contém exigências precisas em relação à estrutura de raciocínio a ser empregada no ato de aplicação”. (ÁVILA, Humberto. Teoria dos Princípios, p. 152).

${ }^{88}$ SARLET, Ingo Wolfgang. O direito Fundamental à moradia na Constituição, p. 228.

${ }^{89}$ A respeito do conflito entre regras e princípios, Riccardo Guastini escreve que, "[...] o que se pede ao juiz constitucional é que confronte não duas regras (nem dois princípios), mas um princípio com uma regra legislativa. Ora, os dois tipos de normas são de todo heterogêneas e a heterogeneidade impede qualquer confronto (como confrontar, por exemplo, o princípio do direito à saúde com uma regra de Direito Civil que admite o ressarcimento dos danos não patrimoniais só em certas condições?)". (GUASTINI, Riccardo. Teoria e ideologia da interpretação constitucional. In: Interesse Público, Ano 8, $\mathrm{n}^{\circ} 40$, novembro/ dezembro de 2006. Porto Alegre: Notadez, p. 244). Nesse mesmo sentido Stenmetz afirma que, "somente haverá colisão real se os direitos fundamentais conflitantes forem estatuídos diretamente pela Constituição, mediante disposição normativa expressa, ou se da Constituição se puder deduzir as normas de direitos fundamentais conflitantes”. (STEINMETZ, Wilson Antônio. Colisão de direitos fundamentais ..., p. 140). Importante registrar que a regra que determina a penhora do bem de família do fiador, não está expressa na Constituição Federal, mas na Lei 8.009/90, art. $3^{\circ}$, inciso VII. Mas pode se pode deduzir da Constituição Federal a norma da justiça comutativa expressa pela busca dos indivíduos pela justiça como objetivo fundamental da República e garantida no art. $3^{\circ}$, inciso I e no art. $5^{\circ}$ da Constituição Federal e expressa em seus vários incisos. Importante decisão do Tribunal de Justiça do Estado do Rio de Janeiro, 10ª Câmara Cível, a respeito da justiça comutativa nos tribunais. "Se o contrato faz lei entre as partes, o equilíbrio do início da contratação deve ser mantido como postulado de justiça comutativa que vincula os contratantes e o próprio Estado. O risco ou “alea” é inerente a todo contrato, sendo injusto e injurídico fazê-lo recair somente sobre uma das partes, no caso, justamente sobre a economicamente mais fraca. (BRASIL. Tribunal de Justiça do Rio de Janeiro. Ap. 1999.001.13905. Rel. Des. Jayro S. Ferreira. Julgado em 14.03.2000). A respeito do conflito de regras e princípios Ruy Eduardo Espíndola escreve que, “[...], é preciso anotar, que as regras são concreções dos princípios; são especificações regulatórias desses; são desdobramentos normativos dos mesmos. Assim, cumpre observar que não se manifestam antinomias, conflitos, colidências entre princípios e regras. Desta forma, quando em confronto dois princípios, um prevalece sobre o outro, e as regras que dão concreção ao que foi desprezado são afastadas, e essas não se aplicarão a determinada hipótese, ainda que permaneçam integradas, validamente, no ordenamento jurídico [...]”. (ESPÍNDOLA, Ruy Samuel. Conceito de Princípios Constitucionais. Ed. Revista dos Tribunais, 1999, p. 70). 
A análise que passará a ser feita a partir de agora envolve a regra da penhora do bem de família do fiador - fundada no princípio da justiça comutativa -, tendo como beneficiário da aplicação dessa regra a pessoa do credor e o princípio da dignidade da pessoa humana, tendo como beneficiário o fiador no contrato de locação (direito à moradia fundado na dignidade da pessoa humana). ${ }^{90}$

A aplicação da proporcionalidade pressupõe uma relação entre meio e fim, em que o fim é o objetivo ou a finalidade perseguida pela limitação (direito de crédito relativo aos alugueres, justiça comutativa) e o meio é a própria decisão normativa, legislativa ou judicial (penhora do bem de família do fiador) fator limitador que objetiva tornar possível o alcance do fim desejado. Essa relação entre meio e fim deve pressupor uma relação adequada, necessária e proporcional.

Passa-se, pois, à análise de dois casos mediante a aplicação do princípio da proporcionalidade $^{91}$ :

a) O primeiro julgado objeto de análise será a Apelação Cível nº 2006.001.22554/RJ, $17^{\text {a }}$ Câmara Cível, tendo como relator o Desembargador Marcos Alcino de Azevedo Torres $^{92}$, contra decisão de primeiro grau que determinou a penhora do bem de família do fiador e sua família para garantir o pagamento de débito da locação. Em seu relatório, o Desembargador ressaltou a importância de registrar que existem diversos outros fiadores no contrato de locação em questão garantindo a execução. Neste caso, conclui-se que a medida é adequada, mas a penhora do bem de família do fiador não é necessária, sendo determinada uma medida menos gravosa para o devedor e sua família $^{93}$. A medida adotada pelo magistrado, de desconstituir a penhora sobre o bem

${ }^{90}$ Violação do princípio da isonomia: o princípio da isonomia determina que todos são iguais em liberdade, propriedade e dignidade, e que a violação desses direitos implica violação a esse princípio fundamental disposto no art. $5^{\circ}$, caput da Constituição Federal de 1988. O art. $3^{\circ}$, inciso VII da Lei $n^{\circ} 8.009 / 90$ determina que o bem de família do fiador, nos casos de obrigação decorrente de fiança em contrato de locação é passível de penhora, para satisfazer o direito de crédito na ação de execução. O fiador, depois de cumprir a sua obrigação perante o credor/locador, exerce o seu direito de regresso perante o afiançado nos mesmos autos da ação executiva, conforme permissão do art. 595, parágrafo único do CPC. Se o afiançado/locatário possuir somente um bem imóvel, que serve de residência para sua família, este imóvel é impenhorável nos termos do art. $1^{\circ}$ da Lei $n^{\circ} 8.009 / 90$. Ao afiançado é permitido opor como exceção a impenhorabilidade do seu bem de família ante a ação regressiva do fiador, que perdeu o seu bem de família por dívidas geradas pelo próprio afiançado no contrato de locação. O afiançado mantém o seu bem de família, garantindo o seu direito à moradia, ao passo que ao fiador é negada a condição de reaver os valores dispendidos na fiança prestada. Pontes de Miranda ressalta que neste caso, a promessa do fiador é maior do que a daquele que gerou a dívida, não devendo ter, portanto, tratamento discriminado em relação à penhorabilidade do seu bem residencial, in casu. (MIRANDA, Pontes de. Tratado de Direito Privado. Parte Especial. Tomo XLIV. 3. ed. São Paulo: Editora Revista dos Tribunais, 1984, p. 180/1).

${ }^{91}$ A respeito do princípio da proporcionalidade e sua aplicação, Gilmar Mendes escreve que, ” [...] há de perquirir-se, na aplicação do princípio da proporcionalidade, se em face do conflito entre dois bens constitucionais contrapostos, o ato impugnado afigura-se adequado (isto é, apto a produzir o resultado desejado), necessário (isto é, insubstituível por outro meio menos gravoso e igualmente eficaz) e proporcional em sentido estrito (ou seja, se estabelece uma relação ponderada entre o grau de restrição de um princípio e o grau de realização do princípio contraposto)”... (BRASIL. Supremo Tribunal Federal, IF nº 164-1 - SP, DJ 14.11.2003).

92 RIO DE JANEIRO. Tribunal de Justiça do Rio de Janeiro. Apelação Cível n ${ }^{\circ}$ 2006.001.22554. $17^{\text {a }}$ Câmara Cível. Rel. Des. Marcos Alcino de Azevedo Torres. Julgado em 12.07.2006.

93 "É importante observar que a técnica da ponderação de bens não corresponde a arbítrio do intérprete, na medida em que se legitima por meio da fundamentação. Assim, não se trata de escolha irracional do intérprete 
de família do fiador e determinar a penhora sobre outros bens de menor valor que a unidade residencial, promoveu a dignidade da pessoa humana do fiador resguardando o seu direito à moradia, mas garantiu também o direito de crédito do exequente através da justiça comutativa, quando abriu a possibilidade de o devedor originário e o fiador fazerem a composição dos valores devidos, na forma de penhora de bens móveis ou na forma de parcelamento do débito. A solução apresentada pelo julgador (penhora de bens móveis e/ou parcelamento do débito pelo devedor originário e fiador) seria menos restritiva do que aquela escolhida pelo legislador (penhora do bem de família do fiador) ${ }^{94}$. O Tribunal do Rio de Janeiro entendeu no sentido de dar parcial provimento ao recurso de apelação, afastando a penhora do imóvel residencial da família do fiador.

b) O segundo julgado objeto de análise é a Apelação Cível nº 70003357910/ RS, $16^{\text {a }}$ Câmara Cível, tendo como relator o Desembargador Paulo Augusto Monte Lopes ${ }^{95}$, contra decisão que julgou parcialmente procedentes os embargos que opôs à execução, reduzindo a penhora à metade pertencente ao embargante, em virtude da morte da fiadora, sua esposa. Neste caso, entende-se que a medida é adequada e necessária, mas não é proporcional, pois as vantagens da promoção do fim a ser alcançado com essa medida são muito menores que as desvantagens causadas pela adoção do meio, pois, nesse caso em especial, ante as condições do fiador (idoso e de capacidade econômica muito baixa), a aplicação da medida que determina a penhora do seu bem de família restringiria demasiadamente o princípio da dignidade da pessoa humana e o direito à moradia de forma extremamente gravosa. Entenderam os julgadores que o tratamento dado ao fiador afronta o princípio da igualdade e atinge o fiador num direito que fere a sua própria dignidade, no caso o direito à moradia. Não há como negar a validade de preservação do princípio da dignidade da pessoa humana, principalmente numa situação particular e delicada como a do fiador que, além de idoso, é pessoa de poucas posses. O Tribunal do Rio Grande do Sul decidiu no recurso de apelação que reconheceu a impenhorabilidade do bem de família em execução por fiança ${ }^{96}$. Os julgadores do Rio Grande do Sul fundamentaram, de forma coesa e com fortes argumentos, a lesão à dignidade humana do idoso, entretanto, equivocadamente não se preocuparam com o direito de crédito do locador/exequente, que poderia também ter sua dignidade da pessoa humana diminuída em razão de estar na dependência de

a determinação de precedência de um princípio sobre o outro em determinadas condições; ao contrário, deve fundamentar o porquê de concluir por aquela precedência, à semelhança do que ocorre nas demais atividades interpretativas”. (CORRÊA, Luciane Amaral. A Constituição concretizada: construindo pontes com o direito público e privado. Org. Ingo Wolfgang Sarlet. Porto Alegre: Livraria do Advogado, 2000, p. 197).

${ }^{94}$ Como a regra não subsistiu ao exame da necessidade, não há por que fazer o exame da proporcionalidade em sentido estrito. "Nesse sentido, a proporcionalidade em sentido estrito expressa o equilíbrio resultante do confronto entre vantagens e desvantagens ocasionadas na medida restritiva ao direito fundamental, necessária à proteção de outro direito fundamental ou bem constitucionalmente protegido”... (FREIRE, Alexandre Reis Siqueira. Colisão de direitos fundamentais e a regra da proporcionalidade. Disponível em: <www.tj.ma.gov.br/site/conteudo /upload/9287/20070305_esmam.doc>acesso em: 19 mar. 2007).

${ }^{95}$ RIO GRANDE DO SUL. Tribunal de Justiça do Rio Grande do Sul. Apelação Cível nº 70003357910.

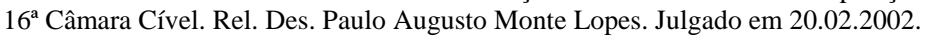

${ }^{96}$ RIO GRANDE DO SUL. Tribunal de Justiça do Rio Grande do Sul. Apelação Cível nº 70003357910. $16^{a}$ Câmara Cível. Rel. Des. Paulo Augusto Monte Lopes. Julgado em 20.02.2002. 
receber os valores devidos, pois se acredita serem estes necessários também a sua subsistência e de sua família e muitas vezes custeiam a sua própria moradia. ${ }^{97}$

Tais situações demonstram que a aplicação ou não da regra que possibilita a penhora do bem de família do fiador deverá ocorrer em cada caso, de forma tópica, avaliando-se as circunstâncias de cada um dos envolvidos na relação contratual de maneira a solucionar a colisão dos direitos fundamentais envolvidos em tais casos denominados difíceis.

\section{CONCLUSÃO}

Como anunciado na parte introdutório, este estudo objetivou analisar a constitucionalidade da penhora do bem de família do fiador e, nesse ensejo, apreciar os argumentos trazidos pelo Supremo Tribunal Federal em 08 de fevereiro de 2006, no julgamento do Recurso Extraordinário n 407.688-8, cuja relatoria foi do Ministro Cezar Peluso. Como mencionado, a maioria dos ministros participantes do julgamento entendeu constitucional a regra que permite a penhora do imóvel residencial do fiador nos termos do art. $3^{\circ}$, inciso VII, da Lei Federal $n^{\circ} 8009 / 90$, na versão que lhe deu a Lei Federal n ${ }^{\circ}$ 8.245/91.

Dessa decisão, destacou-se o voto do relator, Ministro Cezar Peluso, que apresentou o argumento utilitarista, centrado numa análise de justiça distributiva, de que a penhora do bem de família do fiador garante o direito à moradia através da maximização da oferta de imóveis no mercado. Como demonstrado, tal argumento é falho uma vez que não foram apresentados dados e informações que legitimem a suposição da maximização do acesso à moradia através da penhora do bem de família do fiador. Ademais, falha também o argumento ao não demonstrar em que sentido a penhora do bem de família do fiador contribui mais para a suposta maximização do acesso à moradia do que a penhora do bem de família do locatário.

O segundo argumento pela constitucionalidade analisado, dos ministros Joaquim Barbosa, Gilmar Mendes e Sepúlveda Pertence se posiciona pela constitucionalidade com base no fato de que o fiador se obriga voluntariamente, portanto, no pleno exercício da sua autonomia de vontade. Tal argumento, como defendido, não se coaduna com o formalismo centrado na justiça corretiva e no voluntarismo, pois o fato de que o fiador se obriga voluntariamente não legítima a possibilidade de que ele abra mão de sua dignidade e, consequentemente de seu direito à moradia, eis que o respeito à dignidade é premissa de qualquer obrigação em termos voluntaristas.

Destarte, cosoante explicitado neste estudo, os argumentos pela constitucionalidade da penhora do bem de família do fiador, apresentados pelo Supremo Tribunal Federal quando do enfrentamento da matéria, não são sustentáveis na própria racionalidade que lhes poderia servir de fundamento. Não se coadunam, por conseguinte, com uma racionalidade utilitarista ou voluntarista.

Ademais, coube destacar que nas relações contratuais de locação imobiliária e fiança, além de respeitar os princípios relacionados aos contratos, há necessidade de

${ }^{97}$ RIO GRANDE DO SUL. Tribunal de Justiça do Rio Grande do Sul. Apelação Cível no 70003357910. $16^{a}$ Câmara Cível. Rel. Des. Paulo Augusto Monte Lopes. Julgado em 20.02.2002. 
especial atenção quanto aos princípios fundamentais envolvidos na relação em todos os momentos, no sentido de que cada ato deve respeitar os direitos fundamentais concedidos e garantidos aos cidadãos na Carta Magna de 1988.

O princípio da dignidade da pessoa humana institui ao Estado um dever de guiar as ações no sentido de preservar a dignidade da pessoa humana, criando condições que promovam o exercício pleno da dignidade dos indivíduos para que possam promover, de forma parcial ou total, o direito a uma moradia digna, além de disporem do direito à moradia como forma de defesa contra a agressão de terceiros ou contra o próprio Estado.

Apesar do julgado do Supremo Tribunal Federal decidir pela constitucionalidade da penhora do bem de família do fiador, como visto, o postulado da proporcionalidade possibilita ao intérprete flexibilizar a regra de forma tópica nos casos em que houver colisão de direitos fundamentais. A lesão à dignidade humana do fiador no caso concreto deverá ser comprovada e fundamentada, no sentido de que não existe alternativa possível de se satisfazer os créditos do credor/locador e a penhora do seu bem de família acarretará consequências irremediáveis.

Que o exercício de defesa fundado na dignidade da pessoa humana do fiador e no direito à moradia, entretanto, não sirva de bandeira para invocar a proteção de propriedades acima do mínimo considerado essencial social e economicamente ${ }^{98}$. Nesses casos extremos analisados, espera-se do Poder Judiciário e da doutrina a busca por parâmetros normativos constitucionais adequados e em sintonia com a proteção dos direitos fundamentais.

\section{BIBLIOGRAFIA}

ALEXY, Robert. Teoria de los Derechos Fundamentales. Madrid: Centro de Estudios Constitucionales, 1991.

AQUINO, Tomás de. Suma Teológica, II - II. Disponível em: http://www.hjg.com.ar/sumat. Acesso em: 01 mar. 2008.

ARISTÓTELES. Ética a Nicômaco. Tradução, estudo bibliográfico e notas Edson Bini, Bauru, São Paulo: EDIPRO, 2002.

Ética a Nicômacos. 4. ed., tradução de Mário da Gama Kury. Brasília: Editora Universidade de Brasília, 2001.

ASSIS, Araken de. Manual de Execução. 9. ed. rev. e atual. e ampl. São Paulo: Ed. Revista dos Tribunais, 2004.

ÁVILA, Humberto. Teoria dos Princípios, da definição à aplicação dos princípios jurídicos. 5. ed. São Paulo: Malheiros, 2006.

AVVAD, Pedro Elias. Direito Imobiliário: teoria geral e negócios imobiliários. Rio de Janeiro: Renovar, 2006.

98 “[...] o julgador deve estar atento para o desnível de poder econômico entre os contratantes, para uma estrutura de mercado oligopolizada ou de maior concorrência; [...] e, sobretudo, refletir sobre os impactos da decisão nos demais subsistemas sociais, fundamentalmente na economia, diante da interconexão sistêmica do contrato com o mercado e com o sistema econômico”. (TIMM, Luciano Benetti. Função social do contrato:a "hipercomplexidade" do sistema contratual em uma economia de mercado. In: Direito e Economia. Organizador Luciano Benetti Timm. São Paulo: 2005, p. 107 et seq.). 
BARZOTTO. Luis Fernando. Justiça social: gênese, estrutura e aplicação de um conceito. Disponível em: <http://www.presidencia.gov.br/ccivil_03/revista/rev_48/artigos/art_luis.htm > Acesso em: 20 mar. 2008.

BÍBLIA. Português, Bíblia Shedd. 2. ed. rev. e atual. no Brasil.Traduzida em português por João Ferreira de Almeida. São Paulo: Vida Nova; Brasília: Sociedade Bíblica do Brasil, 1997.

BONAVIDES, Paulo. Curso de Direito Constitucional. 11. ed. São Paulo: Malheiros, 2001.

CAMBI, Eduardo. Propriedade no Novo Código Civil: Aspectos Inovadores. In: Revista Síntese de Direito Civil e Processual Civil. v.1, n 1, set/out. 1999.

CANOTILHO, José Joaquim Gomes. Direito Constitucional. 5.ed. Coimbra: Livraria Almedina, 1997.

CORRÊA, Luciane Amaral. A Constituição concretizada: construindo pontes com o direito público e privado. Org. Ingo Wolfgang Sarlet. Porto Alegre: Livraria do Advogado, 2000.

DRESCH, Rafael de Freitas Valle. A influência da economia na responsabilidade civil. In: Direito e Economia. Organizador Luciano Benetti Timm. São Paulo: 2005.

Fundamentos da responsabilidade civil pelo fato do produto e do serviço no direito brasileiro: um debate jurídico-filosófico entre o formalismo e o funcionalismo no direito privado. Porto Alegre: UFRGS, 2005. Dissertação (Mestrado em Direito), Faculdade de Direito, Universidade do Rio Grande do Sul, 2005.

DWORKIN, Ronald. Levando os direitos a sério. São Paulo: Martins Fontes, 2002.

ESPÍNDOLA, Ruy Samuel. Conceito de Princípios Constitucionais. Ed. Revista dos Tribunais, 1999.

FACCHINI NETO, Eugênio. A função social do Direito Privado. In: Revista da Ajuris. Ano XXXIV. N ${ }^{\circ} 105$. Março de 2007.

FERREIRA DA SILVA, Luis Renato. A teoria da causa sinalagmática como fonte de obrigações. Data. Tese (Doutorado em Direito) Faculdade de Direito, Universidade de São Paulo.

FERREIRA FILHO, Manoel Gonçalves. Curso de Direito Constitucional. 26. ed. atual. São Paulo: Saraiva, 1999.

FREIRE, Alexandre Reis Siqueira. Colisão de Direitos Fundamentais e a regra da proporcionalidade. Disponível em: < www.tj.ma.gov.br/site/conteudo/upload/9287/20070305 _esmam.doc>acesso em: 19 mar. 2007.

GOMES, Orlando. Direitos Reais. 19. ed. atualizada / por Luiz Edson Fachin. Rio de Janeiro: Forense, 2005.

GUASTINI, Riccardo. Teoria e ideologia da interpretação constitucional. In: Interesse Público, Ano 8, nº 40, novembro/dezembro de 2006. Porto Alegre: Notadez.

KANT, Immanuel. Crítica da razão prática. Tradução Valério Rohden. São Paulo: Martins Fontes, 2003.

Fundamentação da metafísica dos costumes. Tradução Paulo Quintela. Lisboa: Ediçoes 70, 1960.

Groundwork of the metaphysic of morals: in focus. New York: Routledge, 2002.

. La metafísica de las costumbres: estudio preliminar de Adela Cortina Orts, Traducción y notas de Adela Cortina Orts y Jesus Conill Sancho. 3. ed. Madrid: Tecnos, 2002.

KYMLICKA, Will. Filosofia Política Contemporânea. Trad. Luís Carlos Borges, São Paulo: Martins Fontes, 2006.

LE GAC-PECH, Sophie. La proporcionnalité en droit privé des contrats. Paris: E.JÁ, 2000. 
LOPES, José Reinaldo de Lima. Direitos sociais: teoria e prática... São Paulo: Método, 2006.

LUDWIG, Marcos de C. O direito ao livre desenvolvimento da personalidade na Alemanha e possibilidades de sua aplicação no direito privado brasileiro. In: MARTINS-COSTA, Judith (Org.) A Reconstrução do Direito Privado. São Paulo: Revista dos Tribunais, 2002.

MACCORMICK, Neil. Retórica e Estado de Direito. Trad. Conrado Hubner Mendes, Rio de Janeiro: Elsevier, 2008.

MENKE, Cassiano. A proibição aos efeitos de confisco no Direito Tributário. Dissertação (Mestrado em Direito), Faculdade de Direito, UFRGS, Porto Alegre: 2006.

MICHELON JÚNIOR, Cláudio. Um ensaio sobre a autoridade da razão. Revista da Faculdade de Direito da Universidade Federal do Rio Grande do Sul, Porto Alegre: v. 21, mar. 2002.

MIRANDA, Pontes de. Tratado de Direito Privado. Parte Especial. Tomo XLIV. 3. ed. São Paulo: Editora Revista dos Tribunais. 1984.

MONTORO, André Franco. Introdução à Ciência do Direito. 25. ed. São Paulo: Revista dos Tribunais, 1999.

PEREIRA, Caio Mário da Silva. Instituições de Direito Civil. Vol. IV. Direitos Reais. Rio de Janeiro: Forense, 2003,

Instituições de Direito Civil. Vol. I. Introdução ao direito civil; teoria geral do direito civil. 20. ed. rev. e atual. por Maria Celina Bodin de Moraes. Rio de Janeiro: Forense, 2004.

PESSANHA, Érica. A eficácia dos direitos sociais prestacionais. Disponível em: $<$ http://www.fdc.br/Arquivos/Mestrado/Revistas/Revista08/Discente/Erica.pdf...

Acesso em: 22 mar. 2007.

REINALDO FILHO, Demócrito. Bem de Família do Fiador de Locação pode ser Penhorado - A Nova Decisão do STF. In: Revista IOB de Direito Civil e Processual Civil, ano VII, $n^{\circ} 40$, Mar-abr de 2006.

SARLET, Ingo Wolfgang. A Eficácia dos Direitos Fundamentais. 2. ed. rev. atual. Porto Alegre: Livraria do Advogado, 2001.

A eficácia e efetividade do direito à moradia na sua dimensão negativa (defensiva): análise crítica à luz de alguns exemplos. Texto cedido pelo autor.

Dignidade da pessoa humana e direitos fundamentais na Constituição Federal de 1988. 2. ed. rev. ampl. Porto Alegre: Livraria do Advogado, 2002.

SARLET, Ingo Wolfgang. O direito Fundamental à moradia na Constituição: algumas anotações a respeito de seu contexto, conteúdo e possível eficácia. In: Revista de Direito do Consumidor. N. 46, abril-junho. Ed. Revista dos Tribunais, 2003.

SILVA, José Afonso da. Curso de Direito Constitucional Positivo. 22. ed. rev. e atual. São Paulo: Malheiros, 2003.

SOUZA, Sérgio Iglesias Nunes de. Direito à moradia e de habitação: análise comparativa e suas implicações teóricas com os direitos de personalidade... São Paulo: Ed. Revista dos Tribunais, 2004.

STEINMETZ, Wilson Antônio. Colisão de direitos fundamentais e princípio da proporcionalidade... Porto Alegre: Livraria do Advogado, 2001.

TIMM, Luciano Benetti. Função social do contrato: a "hipercomplexidade” do sistema contratual em uma economia de mercado. In: Direito e Economia. Organizador Luciano Benetti Timm. São Paulo: 2005. 
TIMM, Luciano Benetti; BICCA, Rafael Machado. Direito, mercado e função social. In: Direito e função social, Rafael Bicca Machado e Luciano Benetti Timm (coords.). São Paulo: Quartier Latin, no prelo.

TUCCI, José Rogério Cruz e. A penhora sobre o bem do fiador de locação. In: A penhora e o bem de família do fiador da locação. Coordenação José Rogério Cruz e Tucci. Ed. Revista dos Tribunais, 2003.

TUGENDHAT, Ernest. Lições de Ética. Petrópolis, RJ: Vozes, 1996.

VASCONCELOS, Rita de Cássia Corrêa de. A impenhorabilidade do bem de família: e as novas entidades familiares. São Paulo: Editora Revista dos Tribunais, 2002. - (Coleção Estudos de Direito de Processo Enrico Túlio Liebman; v. 51).

VENOSA, Sílvio de Salvo. Lei do inquilinato comentada: doutrina e prática: Lei no 8.245, de 18.10.1991. 8. ed., São Paulo: Atlas, 2005.

VILLEY, Michel. Filosofia do direito: definições e fins do direito - os meios do direito. Tradução Márcia Valéria Martinez de Aguiar. São Paulo: Martins Fontes, 2003.

VIOLA, Luis Armando. O direito social "moradia" com o advento da Lei $n^{\circ} 10.257$, de 10.07.2001 (Estatuto da Cidade). In: Interesse Público. Ano 8, n 37, maio/junho de 2006. Porto Alegre: Notadez.

WALD, Arnold. Obrigações e Contratos. 16. ed. ver. e atual. de acordo com o Código Civil de 2002, com a colaboração do Prof. Semy Glanz. São Paulo: Saraiva, 2004.

WALZER, Michael. Esferas da Justiça: uma defesa do pluralisno e da igualdade. Tradução Jussara Simões. São Paulo: Martins Fontes, 2003.

WEINRIB. Ernest J. The idea of private law. Havard Cambridge: University Press, 1995.

.Correlativity, personality, and the emerging consensus on corrective justice. Theoretical Inquiries in Law, v. 2, n. 1, jan. 2001. article 4.

ZUCCHI, Maria Cristina. O bem de família e a garantia da fiança locatícia. Francisco Antonio Casconi e José Roberto Neves Amorin (coords.). In: Locações - Aspectos relevantes - Aplicação do novo Código Civil. São Paulo: Método, 2004. 